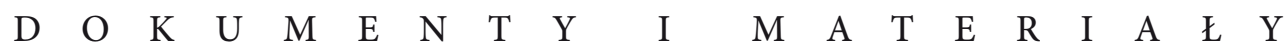

Studia z Dziejów Rosji i Europy Środkowo-Wschodniej XLVI PL ISSN 1230-5057

JOANNA GIEROWSKA-KAŁŁAUR

\title{
STOSUNEK PAŃSTWA ŁOTEWSKIEGO DO MIEJSCOWYCH POLAKÓW I BIAŁORUSINÓW W POCZĄTKACH NIEPODLEGŁOŚCI ŁOTEWSKIEJ
}

Znaczenie nazwy „Inflanty Polskie” ulega stopniowemu zacieraniu w odbiorze powszechnym. Upływ dziewięćdziesięciu minionych lat, paradoksalnie stanowiących zarazem „wiek nacjonalizmów”, sprawił, iż coraz głośniej mówi się dziś o innych narodowościach zamieszkujących Łatgalię, o wszystkich oprócz polskiej. O tej grupie przypomniał jedynie Krzysztof Zajas w swojej znakomitej, aczkolwiek specyficznej pracy ${ }^{1 .}$

Przedstawiam Państwu 8 dokumentów dotyczących realiów dnia codziennego Polaków żyjących na Łotwie w latach 1919-1922. Z części odnalezionych w AAN materiałów korzystał Edward Maliszewski w $1922 \mathrm{r}^{2}$, nie powoływał się jednak na autora wypisów i nie przytaczał ciekawych adnotacji. Pozostałe dokumenty bądź napłynęły do Towarzystwa Straży Kresowej po wydaniu książki, bądź (mowa o innych archiwach) nie były Maliszewskiemu znane ${ }^{3}$. Uważam, że najwyższa pora wprowadzić je do obiegu naukowego. Pozwoli to przede wszystkim na uchwycenie p r o p o r c j i w postrzeganiu wydarzeń, które miały miejsce u zarania niepodległości łotewskiej w Łatgalii. Krainie obecnie egzotycznej nawet dla studentów Studiów Wschodnich, którzy kilka lat temu odbyli tam podróż naukową pod opieką kadry Studium Europy Wschodniej Uniwersytetu Warszawskiego. Ślady polskości są dostrzegalne tylko dla osób, które wiedzą gdzie i czego szukać. Publikacja ta ma też na celu niedopuszczenie do zatarcia w pamięci dramatu Polaków, o których u zarania niepodległości obu krajów nie zadbał ani łotewski, ani polski rząd.

\section{I.}

Letgalia (Łatgalia, Łetgoła) to Inflanty Polskie, część ziem dzisiejszej Łotwy rozciągająca się wzdłuż środkowego biegu Dźwiny i na północ od niej, granicząca z dzisiejszą

${ }^{1}$ K. Zajas, Nieobecna kultura. Przypadek Inflant Polskich, Universitas, Kraków 2008.

${ }^{2}$ E. Maliszewski wykorzystał obszernie Dokument 2 i dlatego nie uwzględniłam go w całości.

${ }^{3}$ Dokumenty $1,3,4,5,6,7,8$. 
Białorusią i Rosją, która wraz z innymi terytoriami znalazła się w Rzeczypospolitej w 1561 r. po dobrowolnym oddaniu się mistrza zakonu krzyżacko-inflanckiego Gotarda Kettlera pod opiekę polskiej korony. Kettler został księciem lennym wobec Rzeczypospolitej w obawie przed moskiewskimi siłami Iwana Groźnego, władając południową częścią Inflant - Kurlandią i Semigalią (lenno polskie do 1795 r.). W 1566 r. Zygmunt August wcielił pozostałe Inflanty do Wielkiego Księstwa Litewskiego i na sejmie lubelskim (1569) przeszły one pod wspólną władzę Korony i Wielkiego Księstwa. Początkowo terytoria przyłączone do Polski (z Rygą, Białym Kamieniem i Parnawą) miały pełna autonomię, zachowując własny sejm i utrzymując odrębne prawa i przywileje. Dopiero sejm walny z 1598 r. zbliżył ustrój Inflant do polskiego, włączając m.in. ich reprezentantów do senatu i izby poselskiej. Konstytucja z 1598 r. wprowadzała podział Inflant na trzy województwa (wendeńskie, parnawskie i dorpackie) z sejmikiem w Wenden. Sojusz państw bałtyckich pod wodzą Stefana Batorego przyniósł zdobycie Dyneburga, a następnie Inflant Środkowych. Rozejm w Jamie Zapolskim (1582) został przedłużony do roku 1622. Szwedzi sukcesywnie odbili w latach 1617-1629 Parnawę, Rygę, Dynemunt (Daugaugrive) i Mitawę. W konsekwencji pokoju w Starym Targu (1629) Szwedzi zatrzymali Inflanty na północ od Dźwiny. Z pozostałej pod polską władzą części województwa wendeńskiego w 1620 r. utworzono województwo inflanckie. W konsekwencji pokoju w Oliwie (1660) Rzeczpospolita utraciła inną część Inflant - Liwlandię zwaną od tego czasu Inflantami szwedzkimi. Na mocy postanowień sejmu polskiego (1667) województwo inflanckie otrzymało tytuł księstwa i zostało podzielone administracyjnie na tzw. trakty: dyneburski, rzeżycki, lucyński i marienhauski. Sejmy odbywały się w Dyneburgu, herbem zaś Księstwa był srebrny gryf w koronie na czerwonym polu z mieczem skierowanym do góry i monogramem SA (Sigismundus Augustus). Inflanty polskie pozostawały we wspólnym władaniu Korony i Wielkiego Księstwa Litewskiego do roku 1795 i stały się częścią Imperium Rosyjskiego dopiero po trzecim rozbiorze Polski.

\section{II.}

Do czasów rozbiorowych problematyka inflancka ma w Polsce literaturę nie tak wielką ilościowo, lecz imponującą jakościowo .

${ }^{4}$ G. Manteuffel, Inflanty polskie poprzedzone ogólnym rzutem oka na siedmiowiekowa przeszłość całych Inflant, J. K. Żupański, Poznań 1879; idem, Z dziejów starostwa Maryenhauzkiego, Wilno po 1909; Z okolic Dźwiny. Księga zbiorowa na dochód czytelni polskiej w Witebsku, [s.n.], Wilno-Witebsk 1912; A. Urbański, Pro memoria. 4-ta seria rozgromionych dworów kresowych, Graf, Gdańsk 1991; Polska a Inflanty: praca zbiorowa / zawierająca rozprawy Edwarda Kuntzego [et al.], przedm. S. Kutrzeba, Instytut Bałtycki, Gdynia 1939; W. Kozłowski, Powstanie kościuszkowskie w Kurlandii, Alma Mater Vilniensis, Londyn 1973; Z. Wójcik, Historia powszechna XVI-XVII wieku, Wydawnictwo Naukowe PWN, Warszawa 2002; Prusy i Inflanty między średniowieczem a nowożytnością. Państwo, społeczeństwo, kultura: zbiór studiów, red. B. Dybaś, D. Makiłła, Wydawnictwo UMK, Toruń 2003; A. Romanowski, Pozytywizm na Litwie. Polskie życie kulturalne na ziemiach litewsko-białorusko-inflanckich w latach 1864-1904, Universitas, Kraków 2003; B. Dybaś, Na obrzeżach Rzeczypospolitej. Sejmik pilityński w latach 1617-1717, Wydawnictwo UMK, IH PAN, Toruń 2004; A. Janicki, Studenci polscy na Politechnice Ryskiej w latach 1862-1918, 
Łotwie i dziejom Polaków na Łotwie na przełomie XIX i XX wieku również poświęcono wiele prac polskich historyków. Przed II wojną światową ukazały się prace K. Kellera (1920)5 $)^{5}$ Edwarda Maliszewskiego (1922) ${ }^{6}$, Jana Cynarskiego (1925) , Jerzego Różyckiego $(1930)^{8}$ i Witolda Sworakowskiego ${ }^{9}$ (1934). Szczęśliwym trafem zachowały się materiały Towarzystwa Straży Kresowej, na których oparł się Edward Maliszewski, a za nim - częściowo - Jerzy Różycki.

Historiografia powojenna opiera się o prace Piotra Łossowskiego $(1990)^{10}$, Andrzeja Maryańskiego (1993), zbiór artykułów zebranych i zredagowanych przez ks. Edwarda Walewandera $(1993)^{11}$, pracę Janusza Albina (1994) ${ }^{12}$ oraz Krzysztofa Zajasa (2008).

$\mathrm{Na}$ odrębne miejsce w historiografii zasługuje dorobek łotewskiego historyka (o odległych polskich korzeniach) Ëriksa Jēkabsonsa ${ }^{13}$, dodajmy - badacza, który prowadził kwerendę również w polskich archiwach.

Wydawnictwo UG, Gdańsk 2005; H. Łowmiański, Polityka Jagiellonów, Wydawnictwo Poznańskie, Poznań 2006; S. Herbst, Wojna inflancka 1600-1602, Inforteditions, Zabrze 2006; G. Manteuffel, Zarysy $z$ dziejów krain dawnych inflanckich, red. i oprac. K. Zajas, Universitas, Kraków 2007 i wreszcie autorską pracę Krzysztofa Zajasa, Nieobecna kultura.

${ }^{5}$ K. Keller, Stosunki narodowościowe, społeczne, ekonomiczne na Inflantach polskich i polityczne $w$ Łatgalii, Rypin 1920 [Według wyszukiwarki KARO w polskich zbiorach bibliotecznych nie zachował się ani jeden egzemplarz tej pracy].

${ }^{6}$ E. Maliszewski, Polacy na Łotwie, 1922, Biblioteczka „Wschodu Polski” nr 8, Wydawnictwo T-wa Straży Kresowej, Warszawa 1922, ss. 34. Praca została opracowana w oparciu o część materiałów przechowywanych w zbiorze TSK w AAN w Warszawie.

7 J. Cynarski, Łotwa współczesna, Biuro Społeczne Literackie, Warszawa 1925, ss. 160, [2] s., [1] k. tabl.: il., err.; $21 \mathrm{~cm}$.

${ }^{8}$ J. Różycki, Polacy na Łotwie, Tow. Opieki Kulturalnej nad Polakami zamiesz. zagr. im. A. Mickiewicza, Warszawa 1930, ss. 23. Opracowane na podstawie materiałów Tow. im. A. Mickiewicza, I Zjazdu Polaków z zagranicy oraz pracy E. Maliszewskiego, Polacy na Łotwie. [Według KARO jedyny egzemplarz w polskich zbiorach bibliotecznych znajduje się w Bibliotece UAM w Poznaniu].

${ }_{9}$ W. Sworakowski, Polacy na Łotwie: uwagi o ich liczbie i rozmieszczeniu, składzie wyznaniowym, podziale wedtug płci i wieku, analfabetyźmie i strukturze społeczno-gospodarczej na podstawie łotewskiego spisu ludności 1930 r., nakł. Instytutu Badań Spraw Narodowościowych,Warszawa 1934, ss. 45, [2] s., [1] k. złoż.: il ; 24 cm. Biblioteka „Spraw Narodowościowych” nr 18, Uzup. odbitka ze „Spraw Narodowościowych" R. VIII, nr 2-3 i 4.

${ }^{10}$ P. Łossowski, Łotwa nasz sasiad. Stosunki polsko-łotewskie w latach 1918-1939, Wydawnictwo Mozaika, Warszawa 1990, ss. 63.

${ }^{11}$ Polacy na Łotwie, red. E. Walewander, Instytut badań nad Polonią i Duszpasterstwem Polonijnym Katolickiego Uniwersytetu Lubelskiego, Redakcja Wydawnictw KUL, Lublin 1993.

12 J. Albin, Polski ruch narodowy na Łotwie w latach 1919-1940, Wydawnictwo UWr, Wrocław 1994.

13 Przytaczam tu wyłącznie artykuły Ē. Jēkabsonsa opublikowane w języku polskim: Stosunki między Łotwa i Białoruską Republika Ludową w latach 1919-1921, „Białoruskie Zeszyty Historyczne” 1997, z. 7, s. 49-62; Zaangażowanie państwowo-polityczne szlachty polskiej z Latgalii (dawnych Inflant polskich) w pierwszej ćwierci XX wieku, „Przegląd Wschodni” 1997, z. 3, s. 513-522; Materiały dotyczące stosunków Łotewsko-polskich i mniejszości polskiej na Łotwie w Państwowym Archiwum Historycznym Łotwy, „Białostocczyzna” 1997, nr 4, s. 91-97; Materiały dotyczace Polski w zbiorach muzeów Łotwy, „Białostocczyzna” 1998, nr 4, s. 103-106; Jeńcy - Łotysze w niewoli polskiej (1918-1921), „Zeszyty Naukowe Muzeum Wojska 
W oparciu o szeroko zakrojone poszukiwania (m.in. w Archiwum Akt Nowych oraz w Archiwum PAN w Warszawie) Jēkabsons doszedł do wniosku, iż w okresie popowstaniowym szlachta polska traktowała ludność łotewską pogardliwie, a to, że jedynie w 1918 roku zachowywała się przyjaźnie wobec Łotwy wynikać miało - według niego - nie z pobudek patriotycznych, lecz interesu grupowego ${ }^{14}$. We wspólnym państwie łotewskim Polacy mieli widzieć wyłącznie sposób na odparcie bolszewizmu i tylko to wspólne zagrożenie sprzyjało chwilowej konsolidacji.

Z kolei Edward Maliszewski oparł się jedynie na części materiałów nadesłanych z Łatgalii do Komitetu Wykonawczego Towarzystwa Straży Kresowej w Warszawie w 1921 r., a z lektury jego pracy (wyd. 1922) nie wynika, że znał wszystkie materiały z roku 1922, które rzucają jednak nieco szersze światło na polityczną grę tamtej epoki.

III.

Stosunki pomiędzy Polakami a Łotyszami w czasie wojny polsko-sowieckiej były dwupłaszczyznowe.

Pierwszą płaszczyznę tych relacji w sposób wyczerpujący omówił Piotr Łossowski. Stanowiły ją stosunki międzypaństwowe, których genezy należy upatrywać w negocjacjach Leona Wasilewskiego z delegacją łotewską na konferencji paryskiej. W czerwcu 1919 r. z nieoficjalną misją zarówno do proalianckiego Karlisa Ulmanisa, jak i stworzonego przez Niemców rządu Andrevsa Niedry dotarł adwokat Władysław Sołtan. Następny polski emisariusz, inżynier Aleksander Lutze-Birk, wskutek zmiany sytuacji militarnej, negocjował ( $w$ trzech podejściach) już tylko z jednym kontrahentem

w Białymstoku” 2000, z. 14, s. 93-102; Prawnicy polscy - posłowie w Sejmie Łotwy (1922-1934), „Palestra” 2002, nr 11/12, s. 79-85; Towarzystwo Zbliżenia Lotewsko-Polskiego na Łotwie $i$ Towarzystwo Zbliżenia Polsko-Łotewskiego w Polsce, „Akant”, R. 7, nr 10, dod. „Świat Inflant” nr 10 (2004), s. 5-6; Walki Wojska Polskiego z Armia Czerwona w okolicach Dyneburga we wrześniu 1919 r., „Zeszyty Naukowe Muzeum Wojska w Białymstoku" 2005, z. 18, s. 50-60; Działalność policji łotewskiej w zajętym przez Wojsko Polskie Dyneburgu w 1920 roku, ,Zeszyty Naukowe Muzeum Wojska w Białymstoku” 2006, z. 19, s. 65-68. Materiały z Międzynarodowej Konferencji Naukowej „W służbie Prawa i Bezpieczeństwa 1918-1939”, Białystok; Zarys wspótpracy łotewskiego i polskiego wywiadu wojskowego 1919-1939, „Studia i Materiały do Historii Wojskowości", t. 44 (2007), s. 279-301, Polska mniejszość narodowa na Łotwie w XIX i XX wieku. Krótka charakterystyka i zarys działalności, w: Europa nieprowincjonalna: przemiany na ziemiach wschodnich dawnej Rzeczypospolitej (Białoruś, Litwa, Łotwa, Ukraina, wschodnie pogranicze III Rzeczypospolitej Polskiej) $w$ latach 1772-1999= Non-provincial Europe: changes on the eastern territories of the former Polish Republic (Belarus, Latvia, Lithuania, Ukraine, eastern borderland of the III Republic) in 1771-1999, red. K. Jasiewicz, [tłum. E. Balcerek et al.; aut. A. Achmatowicz et al. ], Instytut Studiów Politycznych PAN, „Rytm”, Warszawa 1999, s. 287-298. W przywołanym wydawnictwie ISP znajdują się również artykuły innych autorów poświęcone problematyce łotewskiej, a mianowicie: G. Regina, Wokót kształtowania się narodu łotewskiego. Narodowe odrodzenie w Latgalii w XIX i XX wieku, s. 261-269, A. Juszko-Sztekele, Etniczne przymioty mieszkańców Latgalii (dawnych Inflant polskich). Na podstawie badań folklorystycznych $w$ drugiej połowie XIX wieku, s. 280-286, W. Tugaj, Mniejszość łotewska na ziemiach białoruskich w XIX i XX wieku, s. 320-326, I. Poča, Obraz życia Latgalii w gazecie „Gajsma” (1905-1906), s. 512-520.

${ }^{14}$ Ė. Jēkabsons, Zaangażowanie państwowo-polityczne, s. 53. 
- Ulmanisem, przygotowując grunt dla oficjalnego wysłannika polskiego Ministerstwa Spraw Zagranicznych, Bronisława Bouffała, który przybył na Łotwę w październiku 1919 roku. Jego instrukcja poselska obejmowała przeciwdziałanie akcji rosyjsko-niemieckiej na Łotwie i pracę nad łotewsko-polskim zbliżeniem. Ofensywa wojsk niemieckich pod płaszczykiem rosyjskiej białogwardyjskiej armii pułkownika Pawła Bermondt-Awałowa przyspieszyła rozwój wydarzeń. 22 X 1919 r. Polska uznała Łotwę de facto, a przybyłego po pomoc do Warszawy ministra Z. Meieroviciusa w sposób bardzo serdeczny przyjął Naczelnik Państwa, obiecując pomoc w dostawie amunicji i uzbrojenia.

Polska misja wojskowa (Walery Sławek, rotmistrz Radziwiłł) przybyła na Łotwę już po wyeliminowaniu wojsk Bermondta. Polskę i Łotwę jednoczyło wówczas już tylko jedno niebezpieczeństwo - sowieci. Wśród Łotyszy wzrosły niepokoje, czy aby polski sojusznik nie upomni się o Łatgalię i dlatego - z winy łotewskiej - wydłużały (do 30 XII 1919) polsko-łotewskie rokowania wojskowe. Łotysze podejrzewali ziemiaństwo polskie z Łatgalii i „solidaryzujące się z nimi czynniki w Polsce” o zamiary aneksyjne ${ }^{15}$.

Mrzonki Rady Polaków Inflant (od końca 1918 przebywającej w Polsce), reprezentującej jedynie część polskiej społeczności Inflant, o postawieniu katolickiej zapory „kulturze luterańskiej”, „zmuszeniu” Łotwy do przyjaźni i zagwarantowaniu dominującej pozycji dla Polaków w kulturze, gospodarce, nie miały racji bytu i z łotewskiego punktu widzenia było oczywiście nie do przyjęcia. Takiej opinii nie miał również Józef Piłsudski i rząd w Warszawie.

O polsko-łotewskiej współpracy państwowej - politycznej i wojskowej - napisano już bardzo wiele i bardzo dobrze ${ }^{16}$. I to pomimo podjęcia przez stronę łotewską poufnych negocjacji z rządem radzieckim w sytuacji, gdy polskie oddziały wojskowe były już Łotwie niepotrzebne. Wskutek takiego pojmowania przez polityków łotewskich znaczenia słowa „współpraca” w przełomowym momencie dla Polaków, w lipcu 1920 roku, korzystając z odwrotu wojsk polskich, wojska łotewskie obsadziły sporną część 6 gmin powiatu iłłuksztańskiego zamieszkałą przez dużą liczbę Polaków (według Łotyszy - ponad 33\%, według Polaków - ponad 50\% populacji). Polski MSZ polecił posłowi Witoldowi Kamienieckiemu obiecać Łotwie uznanie de iure i ponadto de facto poświęcić tę polską enklawę na rzecz spodziewanego przystąpienia Łotwy do wojny po stronie Polski. Łotwa, kierując się własnym interesem, podpisała traktat pokojowy z Rosją Sowiecką. Stało się to 11 sierpnia 1920 roku - w chwili najtragiczniejszej dla Polaków.

15 „Jak ujawnił w swoich wspomnieniach łotewski szef sztabu gen. Peteris Radzińsz, Łotysze obawiali się, że za polską pomocą kryje się coś bardzo złego" etc. P. Łossowski, Łotwa nasz sąsiad, s. 12.

16 T. Paluszyński, Walka o niepodległość Łotwy 1914-1921, „Bellona”, Warszawa 1999; Łotwa wczoraj, dziś, jutro: materiały pokonferencyjne, red. T. Paluszyński, T. Navickas, L. Marcinkowska, Wielkopolskie Stowarzyszenie Przyjaźni Polsko-Łotewskiej, Instytut Wschodni UAM, Koło Naukowe Wschodoznawców, „Rys-Studio”, Poznań 2003. 
Polska strona rządowa potraktowała to zachowanie Łotyszy ze zrozumieniem. Kiedy wojska polskie ponownie wkroczyły na ziemie litewsko-białoruskie („bunt” Żeligowskiego), oddziały otrzymały rozkaz nieprzekraczania granicy byłej guberni kurlandzkiej na odcinku od stacji Turmonty do miasta Indryca. W rezultacie sporny obszar pozostał w rękach łotewskich. Łotysze nie dostrzegali politycznego znaczenia tego posunięcia, natomiast w szeregach armii generała Lucjana Żeligowskiego widzieli „obszarników polskich” z Łatgalii. W rzeczywistych zamiarach Polski nie leżała aneksja Łatgalii i polskie Ministerstwo Spraw Zagranicznych uczyniło wiele, by zażegnać jesienny kryzys 1920 roku. Ślad łotewskiej nieufności w stosunku do Polaków jednak pozostał, a w niektórych kręgach społeczeństwa łotewskiego niechęć ta znacznie się pogłębiła. Konsekwencje obaw i podejrzeń łotewskich ponieśli Polacy, którzy nie mieli żadnego wpływu na decyzje polskiego rządu - Polacy z Inflant. Ci Polacy, którzy nie stali się politycznymi kontrahentami polityków młodego państwa łotewskiego, a młode państwo polskie poświeciło ich interesy na ołtarzu „wielkiej polityki”. Ludzie, którzy we własnym interesie musieli dążyć do ułożenia stosunków w miejscu swego zamieszkania $\mathrm{z}$ aktualną władzą państwową. A była to sprawa bardzo dla nich trudna. Na ziemiach dzisiejszej Łotwy rozgorzał wewnętrzny głęboki spór. Jak pisał starosta brasławski w 1920 roku (patrz: aneks - Dokument 3): „nienawiść ku Łotwie Kurlandzkiej przejawia się dobitnie w znanym ogólnie przezwisku, określającym Łotyszów kurlandzkich tschiuli ${ }^{17}$, co znaczy czuchna, w zamian Kurlandczycy nazywają Łatgalczyków tschangala ${ }^{18}$. Różnica religii i języka daje swoje dobitne wyniki, obsadzanie zaś stanowisk w Łatgalii przeważnie przez tschiuli rozpala ogień nienawiści” ${ }^{19}$. Więcej informacji o tle konfliktu cytowane źródło nie przynosi, pozostawiając pole do spekulacji. Mieszkańcami Łatgalii byli w owym czasie w dużej części Polacy, z reguły wyznania rzymskokatolickiego i wydaje się, że to nie pod adresem Łotyszy ${ }^{20}$, z reguły luteran, adresowane było przezwisko „tschangala”. Być może ten „przydomek” należał się tym, którzy harmonijnie współżyli z grupą polską?

Politycznymi liderami Polaków byli niewątpliwie: Gustaw Broel-Plater, Julian Salcewicz, Bohdan Szachno, Zygmunt Zabiegło, Janusz Tyszkiewicz, Ireneusz Plater-Zyberk, Wiktor Plater-Zyberk, Jan Zawadzki, a przede wszystkim Antoni Romer z Jampola. Oprócz nich działało tam wielu społeczników, takich jak chociażby dyrektor szkoły K. Próchnik czy też prezeska Polskiej Macierzy Szkolnej Ludmiła Jakubowiczowa. Na

${ }_{17}$ Znane powszechnie wśród mieszkańców Łatgalii przezwisko, określające Łotyszów kurlandzkich, „Tschiuli”, „czuchna”. Według Ëriksa Jēkabsonsa - „,cziulis” - słowa te nic nie znaczą, a pochodzenie tego pejoratywnego określenia jest niejasne.

18 Przezwisko, jakim Łotysze nazywają Łatgalczyków. Według relacji Jēkabsonsa, słowa te również nic nie znaczą, a pochodzenie tego pejoratywnego określenia też jest niejasne.

19 Aneks.

${ }^{20}$ Pierwszy łotewski spis powszechny ludności w trzech powiatach Łatgalji według miejscowości i narodowości. Z dn. 15 VI 1920. [Wypis podpisany przez Antoniego Romera] [adnotacja: Widział Strauch 21 III 1921] [AAN TSK 105 k. 25, 26, 27, 28]. Według tego spisu, Łotyszy w powiecie dyneburskim było 89204 na 172874 osób; w powiecie lucyńskim 91459 na 136266 osób; a w powiecie rzeżyckim 83093 na 13581 osób. 
terenie dawnych Inflant Polskich mieszkali ludzie o znanych w Polsce nazwiskach, które często znajdują się w polskich encyklopediach i leksykonach, polscy właściciele majątków bądź ich dzierżawcy. Mieszkali tam też polscy nauczyciele, urzędnicy, robotnicy i rolnicy.

Według Statystyki Urzędowej z 1905 roku Polacy dysponowali 326 ,jednostkami gospodarczymi na terenie powiatów dyneburskiego, lucyńskiego i rzeżyckiego, które obejmowały w sumie 273323 dziesięcin ziemi. Najwięcej w powiecie rzeżyckim (138 „jednostek gospodarczych" obejmujących 110621 dziesięcin), następnie w powiecie lucyńskim (100 ,jednostek gospodarczych" obejmujących 76472 dziesięcin), a najmniej w powiecie dyneburskim ( 86 ,jednostek gospodarczych” obejmujących 32788 dziesięcin) $)^{21 .}$

Te dane stają się czytelniejsze przy zestawieniu ich z danymi dotyczącymi ogólnego obszaru ziemi w Łatgalii. Dopiero wówczas możemy szacunkowo ocenić siłę ekonomiczną polskiej grupy narodowościowej.

Ogólny obszar ziemi w Łatgaliii22

\begin{tabular}{|l|l|l|l|l|}
\hline Powiat & $\begin{array}{l}\text { Ilość ziemi własności } \\
\text { prywatnej }\end{array}$ & Ilość ziemi nadzielonej & $\begin{array}{l}\text { Ziemie: cerkiewne, } \\
\text { państwowe, instytucji }\end{array}$ & Ogółem \\
\hline dyneburski & 187079 & 193319 & 16598 & 396966 \\
\hline rzeżycki & 216680 & 161667 & 6473 & 384820 \\
\hline lucyński & 279327 & 199148 & 94329 & 572804 \\
\hline$\cdot$ & 683086 & 510334 & 77390 & 1270810 \\
\hline
\end{tabular}

Jak wiadomo, kraje bałtyckie po I wojnie światowej cechowało przeprowadzenie najdrastyczniejszych reform rolnych w Europie. Władysław Studnicki poświęcił temu zagadnieniu pracę ${ }^{23}$, a sprawie reform agrarnych o pierwiastku nacjonalistycznym na Łotwie, Litwie i w Estonii cały jej rozdział.

Pisał o Łotwie (w roku 1927): „Według pierwszych zamierzeń reforma agrarna miała być skierowana przeciwko majątkom rycerskim. Kurlandia i Liflandia posiadały dobra rycerskie, w Inflantach Polskich ich nie było tj. nie było dóbr związanych z przywilejami stanowymi. Reformę agrarną rozciągnięto na Inflanty dla przeobrażenia ich w Letgalję [--] Postanowiono wywłaszczać centry we wszystkich większych majątkach.

${ }^{21}$ Dane ze Statystyki Urzędowej rosyjskiej z 1905 [nie obejmuje pow. dryśnieńskiego i iłłuksztańskiego). Właściciele Polacy. Wypis Antoniego Romera. [AAN TSK 105 k. 13].

${ }^{22}$ Źródło pierwotne: Urzędowa statystyka rosyjska 1905 roku. [Wypis] Ogólne położenie obecne w sprawie agrarnej na Łotwie [z 6 III 1921] podp. Antoni Romer] zatytułowany „Wiadomości statystyczne Inflanty Polskie (Latgalia) 3 powiaty bez powiatu dryśnieńskiego i bez iłłuksztańskiego [AAN TSK 105 k. $22 \mathrm{v}$.

${ }^{23}$ W. Studnicki, Przewroty i reformy agrarne Europy powojennej i Polski, Gebethner i Wolff, Warszawa 1927, ss. 290. 
Osiągnięto ten sam cel: obracanie w ruinę odwiecznych siedzib rodowych"24. Jak pisał Studnicki, łotewska reforma rolna powstała z zasady rosyjskiej „obszczyny” i stała się źródłem korupcji na Łotwie, obdarowani ziemią w krótkim czasie ją sprzedawali. Autor konkludował „Państwo łotewskie stało się organizacją, której jakby głównym celem było ograbianie narodowości niełotewskich na korzyść łotewskiej”25.

Oto nazwiska tych Polaków, których majątki - w wyniku reformy rolnej - zostały zabrane w pierwszej kolejności.

W pow. dyneburskim - Broel-Plater (majątek KRASŁAW wraz z 200-letnim pałacem rodu), Plater-Zyberk ${ }^{26}$ (majątek ARENDOLA), Szacho (majątek JÓZEFOWO), Suryn (majątek NOWYDWÓR), Szadurski (majątek NEWLANY).

W pow. rzeżyckim - Wojciech Dowgiałło (majątek TAWDOWJANY [wyst. też u Studnickiego nazwa Tanbowiany]), - Antoni Romer (majątek JANOPOL), Sapieżyna (majątek WARKLANY), Szadurski (majątek BUKMUJZA), Michał Benisławski (majątek UZUŁMUJŻA), Bohomolec (obywatel Francji narodowości polskiej, majątek ROZENTOWO), Władysław Sołtan (majątek PREZMA).

W pow. lucyńskim - Pruszyński (majątek ZWIERDZIN), Benisławska (majątek KONIECPOL).

W pow. iłłłuksztańskim - Plater-Zyberk (majątek BEBRA), Brodnicki (majątek DUKSZTYGAE) ${ }^{27}$.

Dodajmy, że oprócz wymienionych właścicieli dużych posiadłości w Inflantach Polskich u progu łotewskiej niepodległości mieszkali i inni, mniej zamożni Polacy, m.in. do 1919 roku: Stanisław Swianiewicz ${ }^{28}$, Wacław Wejtko, Wacław Mohl, Marja Mohlowa, Hieronim Mohl, Maurycy Mohl, Wacław Studnicki, cytowany powyżej Władysław Studnicki, Helena Romerówna, nauczycielki Marja Kołłupajłowna i Wiktoria Mostowska, Aleksander Wilunas - syn urzędnika, Adolf Mikłaszewicz - drobny właściciel ziemski, Franciszek Oskierko, Witold Wiścicki ${ }^{29}$. Do Zarządu Związku Polaków na Łotwie (w roku 1922) weszli Polacy z rodzin zasiedziałych na

${ }^{24}$ Ibidem, s. 66-67.

25 Ibidem, s. 68.

${ }^{26}$ Dwaj synowcy polegli w wojnie przeciw bolszewikom przy wyzwalaniu Inflant; pozbawiono majątku Hieronima Oskierkę, którego syn zginął w wojsku polskim oraz Wyszki Mohlów, wykorzystując fakt, iż syn rodu Aleksander Mohl jako oficer wojsk polskich walczył przeciwko bolszewikom.

${ }^{27}$ AAN TSK 105 k. 22. Notatka podp. Ogólne położenie obecne w sprawie agrarnej na Łotwie [6 III 1921].

${ }^{28}$ Stanisław Swianiewicz (ur. 1899 w Dyneburgu na Łotwie, zm. 1997 w Londynie), polski uczony, profesor ekonomii, prawnik, pisarz i sowietolog. Pradziadek został stracony po powstaniu listopadowym, dziadek z bratem uczestniczyli w powstaniu styczniowym, rodzice byli ludźmi wykształconymi, z wysoką pozycją społeczną - ojciec, inżynier kolejnictwa, zajmował stanowisko naczelnika odcinka kolejowego Dyneburg-Orzeł, matka skończyła szkołę dla szlachetnie urodzonych panien w Wilnie na Litwie z wykładowym językiem niemieckim. W 1919 r. został komendantem POW w Inflantach, a po przedostaniu się do Wilna wziął udział w walkach z bolszewikami.

${ }^{29}$ AAN TSK 106 k. 2. Wyciąg z protokołu Zebrania Zadźwińskiego Koła Macierzy, w skład którego wchodzą Polacy obywatele Łotwy oraz Polacy z Inflant, którzy obywatelstwa łotewskiego nie przyjęli. 
Łotwie od lat - panna Stanisława Dowgiałłówna ${ }^{30}$ - prezeska, Antoni Kiełpsz ${ }^{31}$ wiceprezes, Bolesław Benżyk ${ }^{32}$ - sekretarz. W roku 1922 na polskiej liście kandydatów do Sejmu w Okręgu Letgalskim nr 14 znaleźli się - oprócz wspomnianych Antoniego Tałat-Kiełpsza i Stanisławy Dowgiałłównej - również: Jerzy Bryc [prawnik, rolnik z powiatu dyneburskiego], ks. Bronisław Wierzbicki ${ }^{33}$ [dziekan dyneburski], Jarosław Wielpiszewski $^{34}$ [prawnik], Witold Lassan ${ }^{35}$ [rolnik], Ludmiła Jakubowiczowa ${ }^{36}$ [notariusz dyneburski], Jan Wierzbicki ${ }^{37}$ [prawnik], Stanisław Wiścicki ${ }^{38}$ [rolnik], Michał Biedrzycki ${ }^{39}$ [dr med.], Adolf Giedrojć-Juraho [rolnik], Anna Koziczówna [rolniczka], Piotr Swyłan [Szyłan] z Rygi [buchalter z konsulatu], Bolesław Wiszniewski [rolnik], Kazimierz Suprowicz ${ }^{40} \mathrm{z}$ Libawy [sądowy komornik]. W prace Polskiego Centralnego Komitetu Wyborczego (1922) obejmującego 5 okręgów wyborczych (Ryski, Kurlandzki, Zegalski, Liflandzki, Letgalski) w okręgu Letgalskim zaangażowali się: Jan Wierzbicki (obwód Dyneburg, prezes komitetu obwodowego), Teofil Sarnowski [ew. Sosnowski - tekst słabo czytelny], a po jego wyjeździe do Polski Jan Mickiewicz (obwód krasławski, powiat dyneburski), Stanisław Wiścicki (kierownik obwodu ruszańskiego w powiecie dyneburskim), Witold Lassan (obwód rzerzyski/ rzeczycki). Gaddel Godlewski ${ }^{41}$ był tylko pro forma kierownikiem obwodu lucyńskiego (nie wykazał inicjatywy, realną pracę Centralnego Komitetu Wyborczego wykonywał $\mathrm{w}$ tym powiecie Tomaszewicz oraz również bardzo popularny dr Biedrzycki). Ponadto w prace komitetu wyborczego zaangażowali się Wacław Olechnowicz ${ }^{42}$, Wilczyński - robotnik z Dyneburga o nieustalonym imieniu, który czynnie przeciwstawiał się wpływom agentów sowieckich wśród mas robotniczych Dyneburga, oraz Bronisław Kozakiewicz.

Oprócz Polaków na terenie trzech powiatów Łatgalii mieszkali również Łotysze, Niemcy, Wielkorusi, Żydzi, Litwini i Estończycy, a także - Białorusini.

${ }^{30}$ Przyrodniczka, studiowała $\mathrm{w}$ „krakowskim uniwersytecie”, pracowała w szkolnictwie polskim w Łatgalii, przed laty rozparcelowała swój majątek na korzyść miejscowych chłopów, w 1922 dzierżawiła Tawdowiany.

${ }^{31}$ Prawnik, ukończył „Piotrogrodzki Uniwersytet”, inspektor szkół polskich.

${ }^{32}$ Nauczyciel polskiego w gimnazjum w Dyneburgu.

${ }_{33}$ Podobno człowiek „słabego charakteru, znajdujący się pod wpływem kleru łotewskiego”, prowadził akcję przeciwko innym Polakom niepraktykującym religii katolickiej [np. przeciwko innemu polskiemu kandydatowi Jerzemu Brycowi].

${ }^{34}$ Były sędzia ziemski, prezes (w 1922 r.) Zarządu Gminnego, rolnik powiatu lucyńskiego.

${ }^{35}$ Kierownik obwodu [wyborczego] rzeżyckiego, określany mianem człowieka wielkich ambicji, sekretarz (1922) Związku Drobnych Właścicieli i Dzierżawców.

${ }^{36}$ Prezeska Macierzy Szkolnej.

37 Były sędzia, nauczyciel szkoły polskiej (1922).

${ }_{38}$ Przybity niedolą materialną, posiadający na utrzymaniu bardzo liczną rodzinę.

39 Prezes (1922) Rady Miejskiej w Lucynie, b. szanowany i ceniony tak w mieście, jak i w powiecie (Prezes Koła Polskiego w Lucynie).

${ }^{40}$ Prezes Towarzystwa Polskiego w Lipawie.

${ }^{41}$ Nauczyciel polskiej szkoły powszechnej.

42 „Szczery patriota w b. trudnej sytuacji materialnej”. 
Dysponujemy wypisem $\mathrm{z}$ epoki $\mathrm{z}$ pierwszego łotewskiego spisu powszechnego $\mathrm{z}$ dnia 15 VI 1920 r. ludności w trzech powiatach Łatgalii według miejscowości i narodowości ${ }^{43}$. Dodajmy - spisu sfałszowanego według zgodnych relacji Polaków łotewskich. Oryginał wypisu zaopatrzony jest w adnotację Antoniego Romera z Jampola: „Władze łotewskie przy spisywaniu ludności usilnie starały się zmniejszyć liczbę Polaków na korzyść liczby Litwinów, a zwłaszcza Białorusinów co wielokrotnie stwierdziłem było, wobec czego spis niniejszy uważany być powinien za krzywdzący Polaków a faworyzujący natomiast Litwinów, a zwłaszcza Białorusinów" ${ }^{44}$.

W raporcie Jana Wiścickiego ${ }^{45}$ z 1922 roku czytamy: „Główny nacisk akcji białoruskiej jest skierowany przeciwko szkolnictwu polskiemu. Pan Jezowitow grozi nauczycielstwu polskiemu, iż zabierze wszystkich uczni polskich do szkół białoruskich. Prefektura miasta Dyneburga wyraźnie hołduje wszelkiej akcji białoruskiej w tym kierunku nieraz dając dowody współdziałania Białorusinom w wykreślaniu z polskich szkół dzieci Polaków i przenosząc je do białoruskich, opierając się na tendencyjnym i wielce stronniczym spisie ludności w roku 1920 gdzie niemal że wszystkich Polaków zaliczono jako Białorusinów"46.

Wyniki spisu z 15 VI 1920 są zastanawiające, szczególnie w sytuacji, gdy skonfrontuje się je $\mathrm{z}$ wyrywkowymi danymi (zawarte są w cytowanym w Aneksie we fragmentach dokumentu z 2 grudnia 1922 pióra Jana Wiścickiego zatytułowanym „Przebieg Polskiej Akcji Wyborczej do Sejmu Łotewskiego w Rydze") wyników wyborów do Sejmu Łotewskiego z 1922 roku, gdzie jak wiadomo Polacy ponieśli z powodu własnych błędów sromotną $\mathrm{klęskę}^{47}$. Czy logicznym wytłumaczeniem faktu, iż w ekstremalnie "niesprzyjających” warunkach wyborów 1922 roku na listę polską głosowało w Krasławiu 260 „nie-Polaków”, w Andrepnie - 85 nie-Polaków, w Kownatach - 95 nie-Polaków etc., nie jest przyjęcie hipotezy, iż w trakcie spisu 1920 r. źle określono narodowość tych wyborców? ${ }^{48}$

Wydawałoby się, że pokłosie działalności Rydza-Śmigłego i Bułak-Bałachowicza, nie mówiąc już o kilkuset polskich nagrobnych krzyżach, które stanęły nad poległymi w obronie niepodległości Łotwy Polakami, powinno stanowić podwaliny pod przyjazne stosunki polsko-łotewskie, również na szczeblu powiatów łatgalskich. Przesłany do Wydziału Wykonawczego Towarzystwa Straży Kresowej tekst polemiki ${ }^{49} \mathrm{z}$ artykułem

${ }^{43}$ Pierwszy łotewski powszechny spis ludności w trzech powiatach Łatgalii według miejscowości i narodowości. Z dn. 15 VI 1920. [Wypis podpisany przez Antoniego Romera] [adnotacja: Widział Strauch 21 III 1921] [AAN TSK 105 k. 25, 26, 27, 28].

${ }^{44}$ Ibidem.

${ }^{45}$ AAN TSK 106 k. 9-21. Stosunki polsko-łotewskie. Rządy łotewskie. Nastroje polskie w Łatgalji, podp. JW[iścicki]. $16 \mathrm{~V} 1922$.

${ }^{46}$ Ibidem.

${ }^{47}$ Jak inaczej zinterpretować wynik wyborczy w Dyneburgu, gdzie 3838 Polaków głosowało na inne listy niż polska lub też nie głosowało wcale? Zob. Aneks.

48 Zob. Aneks.

49 AAN TSK 105 k. 5-10 1920, grudzień. Z Łotwy. [Polemika „więcej godności”] Odpowiedź p[anu] Semproniusowi (Robotnik, 30 XI 1920 N. 326) na artykuł wstępny „W sprawie Łotwy”. Podp. Kresowy. 
wstępnym „Robotnika” świadczy o zjawisku wprost przeciwnym. Nieznany z nazwiska autor tego tekstu [czyżby Antoni Romer z Jampola?] nie bez pewnych podstaw zwracał uwagę, iż „doświadczenie i logika wskazują, że Rosja i Niemcy zawsze wspólną politykę prowadzić będą, zwłaszcza jeśli będzie chodziło o pochłonięcie niedogodnej odrębności sąsiada [--] każde więc z państw, jak Litwa, Łotwa, nie mówiąc o Białorusi i Ukrainie - nie może istnieć bez poddawania się wpływowi ekonomicznemu, politycznemu sąsiadów" i konstatował, iż Łotysze zamiast szukać sojusznika do walki z rzeczywistym zagrożeniem oddali się tępieniu śladów polskości („wojska łotewskie umyślnie niszczą pozostałości polskiej kultury po dworach [np.] bibliotekę w Prezmie p. W. Sołtana, obecnie wojewody warszawskiego"). Autor polemizował też z wysokością podanej przez „Robotnika” liczby populacji polskiej w Łatgalii (50 000), korygując, iż w rzeczywistości Polacy stanowią 14\% (ok. 88 000) ${ }^{50}$. W iłłuksztańskim powiecie miało być nie mniej jak 40\% Polaków, w brasławskim 58\% Polaków.

Niepokojąco zabrzmiały w tym tekście słowa krytyki aktywności posła Bronisława Bouffała. Działalność ta została lapidarnie określona zdaniem: „Coraz śmielej łotewska miotła wymiata nas ze szkoły”. Polacy łatgalscy spodziewali się, że polski poseł zadba o „wymaganie od rządu łotewskiego przyzwoitego zachowania się względem uczuć narodowych Polaków na Łotwie”, a tymczasem w powszechnym odczuciu „naraża[ł] powagę państwa polskiego na szwank, czego przecież poseł polski czynić nie może. Nam tutejszym wciąż się widzi, że coś tu nie tak jak trzeba”. Polaków z Łatgalii niepokoiło „rozporządzenie p. Laury, prezesa Szkolnego Miejskiego Rzeżyckiego Urzędu, zakazujące pod groźbą represji noszenia przez uczniaków polskiej szkoły orzełka na czapkach; argumentując to - «i teraz Polacy urządzają powstania»”.

Społeczność polska w Łatgalii boleśnie odnotowała memoriał o Łotwie łotewskiego Ministra Spraw Zagranicznych Z. Meierovicsa [Mejerowicza] przedstawiony w Lidze Narodów (w XI 1920 r., w miesiąc po przyjęciu listów akredytacyjnych dyplomatyczno-wojskowej misji Białoruskiej Republiki Ludowej), w którym faktowi istnienia ludności polskiej w sytuacji, gdy omawiano problematykę związaną z innymi grupami mniejszościowymi Łotwy, nie poświęcono ani jednego słowa.

Reforma rolna $-\mathrm{z}$ definicji - nie mogła być przez ziemian polskich przyjęta z entuzjazmem, ale dotkniętych nią Polaków bolało przede wszystkim to, że czuli się członkami gorszej kasty. „W wolarskim powiecie Łotyszom pozostawiono 300 ha, Polakom - 50 ha, przy tym wszystkim Łotwa uważa się za państwo z Polską zaprzyjaźnione” ${ }^{51}$. Jak słusznie zauważył Piotr Łossowski, „obie strony traktowały

${ }^{50}$ Cyfra 70000 padła w dokumencie przechowywanym w AAN (TSK 105 k. 11) zatytułowanym „Oświadczenie w sprawie przeprowadzanej reformy agrarnej na Łotwie” Ryga 7 II 1921. Podp.: Gustaw Broel-Plater, Julian Salcewicz, Bohdan Szachno, Zygmunt Zabiegło, Antoni Romer, Janusz Tyszkiewicz, Ireneusz Plater-Zyberk, Wiktor Plater-Zyberk

Jan Zawadzki. Z upoważnienia Tadeusza Dymszy, Leona Plater-Zyberka I Jana Plater-Zyberka Antoni Romer.

${ }^{51}$ Stosunki łotewsko-polskie jątrzyła również sprawa Polaków radnych m. Dyneburga wydalonych bezprawnie przez p. Berzinia, Naczelnika Łatgalii, określanego charakterystycznym mianem polakożercy, 
reformę rolną nie tylko jako problem społeczny i gospodarczy, lecz w równej mierze polityczny" 52 . Rząd łotewski traktował ją jako ważny środek łotyszyzacji kraju, uparcie widząc w łatgalskich Polakach niebezpieczną siłę dla swojej państwowości.

Łotyszy w Łatgalii było stosunkowo mało. Byli tam natomiast włościanie, którzy modlili się po polsku, a rozmawiali gwarą białoruską. Liczna grupa, którą Polacy - nie bez podstaw historycznych - uważali za swoją. Do przywództwa tej warstwy aspirowali również politycy BRL - struktury państwowej bez ziemi i narodu. Jak wynika z relacji Jana Wiścickiego i Antoniego Romera (zob. Dokument 3), w praktyce dla władz łotewskich nie było ważne, z jakim językiem wykładowym szkół domagali się dla swoich dzieci ci właśnie mieszkańcy Łatgalii.

Z łotewskiego punktu widzenia pożądane było znalezienie przeciwwagi dla elektoratu polskiego. Z kolei dla świeżo usadowionych na Łotwie polityków BRL była to niewątpliwie znakomita okazja do umocnienia swojej pozycji.

Wydane zostało przez Polaków z Łotwy „Oświadczenie w sprawie przeprowadzanej reformy agrarnej na Łotwie" ${ }^{53}$, które zaadresowano do Wydziału Wschodniego MSZ, Poselstwa Rzpltej na Łotwie i do konsulatu polskiego na Łotwie w Rydze. Oświadczenie to wzywało władze polskie w Warszawie do obrony - według szacunków sygnatariuszy - rzeszy 70000 Polaków na Łotwie, którzy byli oddalani ze stanowisk oraz zmuszani do opuszczania swoich siedzib. Autorzy oświadczenia ze swojej strony deklarowali gotowość do poniesienia ofiar na rzecz bezrolnej lub małorolnej ludności polskiej w celu - jak to określano - „ustalenia jej na ziemi”. To samo gremium tego samego dnia przedstawiło swoje postulaty w sprawie reformy agrarnej na Łotwie ${ }^{54}$. Reforma w opinii Polaków winna być przeprowadzona od kresów do centrum, stopniowo, spłata powinna następować w złocie po cenach transakcji z poprzedzającego 10-lecia. Reszta majątków (lasy) powinna być pozostawiona do pełnej używalności, a właściciele nie powinni być pozbawiani prawa do samodzielnej likwidacji reszty swojego majątku.

Notatka Antoniego Romera z 6 III $1921^{55}$ świadczy dobitnie, iż żaden z polskich postulatów nie został przez władze łotewskie uwzględniony. Czytamy w niej :

jak też niedopuszczenie do Rady Miejskiej w Rzeżycy ani jednego Polaka w odwecie za sprawę burmistrza Jana Łajana, oburzała sprawa aresztowania i skazania na więzienie i wysoką grzywnę p. Terleckiego, burmistrza $\mathrm{m}$. Krasławia oraz organisty z tego miasteczka - za rozdawanie odezw legalnie działającej i oficjalnie uznanej przez władze „Tymczasowej Rasy Organizacji Polskich na Łotwie”.

${ }^{52}$ P. Łossowski, Łotwa nasz sąsiad, s. 21.

53 AAN TSK 105 k. 11 „Oświadczenie w sprawie przeprowadzanej reformy agrarnej na Łotwie” Ryga 7 II 1921. Podp.: Gustaw Broel-Plater, Julian Salcewicz, Bohdan Szachno, Zygmunt Zabiegło, Antoni Romer, Janusz Tyszkiewicz, Ireneusz Plater-Zyberk, Wiktor Plater-Zyberk, Jan Zawadzki. Z upoważnienia Tadeusza Dymszy, Leona Plater-Zyberka I Jana Plater-Zyberka - Antoni Romer.

${ }^{54}$ AAN TSK $105 \mathrm{k}$. 12. Postulaty w sprawie reformy agrarnej przeprowadzonej obecnie na Łotwie. Ryga 7 II 1921. Podp.: Gustaw Broel-Plater, Julian Salcewicz, Bohdan Szachno, Zygmunt Zabiegło, Antoni Romer, Janusz Tyszkiewicz, Ireneusz Plater-Zyberk, Wiktor Plater-Zyberk, Jan Zawadzki. Z upoważnienia Tadeusza Dymszy, Leona Plater-Zyberka I Jana Plater-Zyberka - Antoni Romer.

${ }_{55}$ AAN TSK 105 k. 22 mps - 22 v rkps - 23 mps. Ogólne położenie obecne w sprawie agrarnej na Łotwie [z 6 III 1921] podp. Antoni Romer. 
„Obecnie wszystkie bez żadnego wyjątku majątki już są zarejestrowane razem z budynkami i inwentarzem, którego sprzedawać nie wolno. W aktach rejestracyjnych i innych, właściciel jest stale z urzędu nazywany «były właściciel» i jako taki powinien się podpisywać. W stadium obecnym reformy jest wyznaczenie działek ziemi właścicielom od 50-100 ha, oddanie przez Rząd całej reszty majątku w dzierżawę okolicznej ludności - lasy zaś są w ciągu całej obecnej zimy pospiesznie i rabunkowo wszędzie eksploatowane. O zapłaceniu jakiegokolwiek odszkodowania za wywłaszczane dobro obecnie - nie ma mowy. Jest tylko wzmianka w prawie agrarnym z dnia 16 września 1920 roku, że wysokość wynagrodzenia będzie określona później przez osobne prawo, uchwalenie którego konstytuanta łotewska umyślnie wciąż odwleka, bo na odszkodowanie za wywłaszczoną własność nie mieli mieć prawa ci, którzy wydobyli już z majątku włożony w ziemie kapitał’.

Powszechną uwagę badaczy przykuł dotychczas fakt kosztów reformy rolnej, jakie poniosła polska grupa posiadająca. Zignorowanie przez Łotyszy polskiej ścieżki wyjścia z patowej sytuacji nie wynikało z przyczyn ekonomicznych tylko politycznych. $\mathrm{Z}$ łotewskiego punktu widzenia nieuświadomiony narodowo włościanin nie mógł otrzymać ziemi za aprobatą jej poprzedniego właściciela, a więzi między nim a dworem musiały być przecięte. Najprostszym sposobem było wyeliminowanie dworu.

Beneficjentami polityki łotewskiej wobec posiadającej i świadomej polskiej grupy narodowej stanowiącej znaczącą siłę ekonomiczną Łatgalii stali się przebywający na Łotwie politycy Białoruskiej Republiki Ludowej.

Pierwsze bezpośrednie kontakty zostały nawiązane latem 1919 roku. Konsulat BRL w Rydze zaczął działać na przełomie lipca i sierpnia. Działalność misji dyplomatycznej BRL i kilku przybyłych do Rygi działaczy z Grodzieńszczyzny uaktywniła ryską społeczność białoruską. Jak zauważył Ēriks Jēkabsons „życzliwość do Białorusi była zauważalna zarówno w kręgach politycznych, jak i w społeczeństwie Łotwy" ${ }^{56}$.

Jedyną kwestią sporną w stosunkach BRL z Łotwą była początkowo (1919) sprawa powiatu dynaburskiego. Białorusini, zgodnie ze swoim maksymalnym roszczeniowo programem terytorialnym, rościli pretensje do jego wschodniej części (jak też powiatów lucyńnkiego i rzeżyckiego). Jednym słowem, do terytorium, gdzie w spisie z czerwca 1920 roku pojawiła się - dla Polaków dość niespodziewanie - duża liczba Białorusinów.

Lektura dotychczasowych ustaleń Ėriksa Jēkabsonsa pozwala na postawienie hipotezy zaskakująco prosto tłumaczącą tę sytuację. Na przełomie listopada i grudnia 1919 roku na podstawie osiągniętego wcześniej porozumienia rozpoczęto demobilizację obywateli BRL z armii łotewskiej. Obywateli Białorusi (BRL) nie powoływano już więcej do wojska łotewskiego, a pracownicy konsulatu Białorusi, będąc zainteresowanymi zwiększeniem liczby obywateli swego państwa, nie wnikali, czy aplikujący do obywatelstwa białoruskiego istotnie mieli ku temu podstawy i zadowalali się ustnym wyrażeniem woli.

Włościanie modlący się po polsku, a w domach „białoruszczący”, podobnie jak i na innych ziemiach białoruskich, nie posiadali wykrystalizowanej świadomości narodowej.

${ }_{56}$ Ė. Jēkabsons, Stosunki między Łotwa i Białoruską Republiką Ludowa w latach 1919-1921, „Białoruskie Zeszyty Historyczne", 7/1997, s. 52. 
Wiedzieli, że nie są panami i dodatkowo w ich zasięgu pojawiała się możliwość uniknięcia uciążliwego obowiązku wojskowego. (Tym bardziej że na egzekwowanie tego obowiązku przez BRL, chociażby ze względu na politykę Łotwy wobec Białorusinów w sprawach tworzenia oddziałów wojskowych, bynajmniej się nie zanosiło.)

Politycy BRL pozyskiwali konkretny i „policzony” naród białoruski.

$\mathrm{Z}$ kolei Łotysze odczuwali duży dyskomfort $\mathrm{z}$ racji istnienia na swoim terenie silnej ekonomicznie grupy „polskiej szlachty” cieszącej się poparciem całej, nie tylko szlacheckiej, polskiej społeczności. Akcja „Zima” musiała tylko wzmocnić dumę narodową tej grupy ${ }^{57}$. Trzeba też przyznać, iż z łotewskiego punktu widzenia lepiej było mieć w roku 1920 liczną populacje słabych ekonomicznie, społecznie i politycznie Białorusinów, niż analogiczną - silną i świadomą swych roszczeń, oczekiwań i praw - populację Polaków.

Statystyczne zestawienia nie mogą oddawać rzeczywistego stanu rzeczy. Kompleks Łotyszy wobec łotewskich Polaków mógł wyzwolić w Łotyszach bardzo niedobry dla obu narodów mechanizm społeczny, o którym pisze starosta brasławski w swoim raporcie z przełomu grudnia 1920 i stycznia 1921 (zob. Aneks). Przytoczone fakty i hipotezy wskazują na okoliczności, które mogły doprowadzić do zniekształcenia wyników spisu z 15 VI 1920.

Trzeba też zauważyć, że od chwili przeprowadzenia spisu zmieniła się polityka władz Łotwy w stosunku do BRL. Moment wspólnoty łotewsko-białoruskich interesów minął. Zaczęto, co prawda sporadycznie, weryfikować przynależność państwową Białorusinów, zamknięto konsulat w Liepaja, Łotwa zaniechała popierania BRL na forum międzynarodowym. Po zawarciu pokoju pomiędzy Łotwą a Rosją Radziecką oficjalni przedstawiciele rządu BRL stali się dla Łotyszy wyjątkowo niewygodnym rezydentem. Wkrótce po utworzeniu w Rydze (20 X 1920) zjednoczonego bloku narodowego, w wyniku nacisków rządu łotewskiego wielu polityków BRL zaczęło przygotowywać się do wyjazdu. A rozkład głosów w wyborach 1922 r., dzięki wyjątkowo nieudanej strategii wyborczej Polaków ${ }^{58} \mathrm{i}$ ich wewnętrznych, wręcz samobójczych sporów ${ }^{59}$, był początkiem totalnej minimalizacji roli obu grup narodowych na Łotwie.

${ }^{57}$ Polscy „legioniści” musieli imponować i innym grupom zamieszkującym Łotwę, skoro Łotysze zaanektowali dla siebie chociażby linie melodyczne polskich piosenek wojskowych. Mój ojciec, Zbigniew Gierowski (ur. 1927) pamięta z dzieciństwa, jakie kolosalne wrażenie wywierał na warszawiakach w czasie okupacji II wojny światowej łotewski oddział wojskowy maszerujący w roku 1943 co tydzień do łaźni ulicami warszawskiej Ochoty i śpiewający co prawda łotewską pieśń, ale na melodię „Rozkwitały pęki białych róż”.

${ }^{58}$ Ordynacja wyborcza zezwalała na system list otwartych, można było skreślać i dopisywać kandydatów z innych list, co wywołało chaos. Szesnastoosobowa Rada Związku Polaków w Łotwie wraz Zarządem Związku utworzyła Polski Centralny Komitet Wyborczy (cieszący się opinią ciała mało sprężystego). Teren Łotwy podzielono na 5 okręgów wyborczych (ryski, kurlandzki, zemgalski, liflandzki, letgalski). Okręg wyborczy łatgalski podzielono na pięć obwodów (w Dyneburgu prezesem komitetu obwodowego został Jan Wierzbicki, w obwodzie krasławskim - Teofil Sarnowski, a po jego wyjeździe do Pilski, Jan Mickiewicz, w obwodzie ruszańskim Stanisław Wiścicki, w obwodzie rzerzyskim Witold Lassan, a w obwodzie lucyńskim Gaddel Godlewski), a w obwodach powstawały parafialne komitety wyborcze, które za swe zadanie pierwszoplanowe uważały uświadamianie ludności polskiej.

${ }_{59}$ W dwóch kolejnych raportach (Raport z 21 VII 1922, [z Dyneburga]. Podp. inicjałami JM (JW. ?) [J. Wiścicki], AAN TSK 106 k. 22-23 rkps. Raport ze stosunków na Łotwie. Inflanty 27 IX 1922. Podp. J. 
W tabelach narodowościowych zamieszczonych w wydanej w 1927 r. pracy Alfredsa Bilmanisa La Lettonie pittoresque et sa vie actuelle (właśc. Alfr. Bilmans, V. Pengerots Riga: „Ziemnieka Domas”, 1927) Białorusinów na Łotwie już nie ma.

\section{\& Dokument 1}

\section{9, grudzień, 18. Raport pow[iatu] brasławskiego Straży Kresowej ${ }^{60}$} AAN TSK 253 k. 37-37 v.

Powiat brasławski graniczy z Litwą i z Łotwą, która zajmuje nam obecnie 5 gmin, mianowicie: smiższej[?], borawską, skudelińską [skrudelińską], boruską, dameńską i kałkuńską ${ }^{61}$. Granica nasza i Litwa biegnie wzdłuż miejscowości m. Dangieliszki, później na zachód od miasteczka Tylża, następnie na zachód od stacji kolejowej Turmonty i łączy się z granicą łotewską. Granica ta, począwszy od nieco na zachód od st[acji] Turmonty, biegnie przez wieś Miednice, dalej m. Jakubowo, maj[ątek] Matuliszki, następnie przez wieś Berze i za wsią Krzywosiekanie łączy się z Dźwiną.

Powiat ten jest niezmiernie wydłużony, z Brasławia bowiem do zachodniej granicy powiatu jest około 70 wiorst. Utrudnia to ogromnie pracę, gdyż przebywanie takich przestrzeni przy ograniczonych środkach lokomocji nie należy do rzeczy łatwych.

Utrudniają pracę we wsi również powtarzające się ciągle samowolne rekwizycje, prowadzone przez żołnierzy z całą bezwzględnością. Pomimo tak krótkiego czasu, dowiedziałem się już o 50 wypadkach, gdzie żołnierze, grożąc natychmiastowym rozstrzelaniem, zrabowali mięso, kury, masło itp. Urzędujący tu jedyny wojskowy, kierownik Komisji zakupu zboża 2 Armii na interpelację moją w tej sprawie odpowiedział mi, iż jest bezsilnym i nic na to poradzić nie może.

Zauważyłem, iż na ogół ludność jest bardzo przychylna dla Polski, lecz zrażona tego rodzaju postępowaniem wojska i dlatego w wielkim stopniu nieufna. Dużą pomocą dla naszej sprawy byłoby dostarczenie soli i nafty, gdyż ludność, otrzymując te produkty z Litwy, oczywiście tam ciągnie.

Powiat liczy 15 gmin. Rady gminne działają tylko w paru gminach. Szkół funkcjonujących już i takich, które w tych dniach mają być uruchomione, powiat posiada 23. Jednak o ile zdążyłem się dowiedzieć, nie wszyscy nauczyciele mają odpowiednie kwalifikacje. Nie ma w tym względzie żadnej kontroli, gdyż referenta oświatowego nie ma. W ogóle wszystkimi sprawami powiatu zajmuje się na razie zastępca starosty

Wiścicki AAN TSK 106 k. 24-31 mps) czytamy o podziale społeczeństwa polskiego na dwa obozy. „Podział wynikał z osobistego antagonizmu pomiędzy dwoma konsulami polskimi Lutze-Birkem w Rydze i Świerzbińskim w Dyneburgu. Świerzbińskiemu powierzono polską akcję wyborczą nieudolnie koniec końców prowadzoną".

${ }^{60}$ Zachowało się sprawozdanie inspektora szkolnego ZCZW w powiecie brasławskim z 30 lipca 1920 roku, J. Szelągowskiego, który podjął swe obowiązki w tym powiecie 15 XII 1919 roku. Na podległym mu terytorium powstało 37 szkół, na żądanie ludności 35 szkół z językiem wykładowym polskim i 2 szkoły z językiem wykładowym rosyjskim. W szkołach tych uczyło 41 nauczycieli, z których 10 było wykwalifikowanych, a 31 niewykwalifikowanych, (BPK ZCZW nr akc. 1728 k. 3-4).

${ }^{61}$ W słabo czytelnym oryginale wymienionych jest sześć, a nie pięć nazw gmin. 
p[an] Radecki-Mikulicz wraz z swoją sekretarką. Więcej nikogo nie ma. Cały personel ze starostą na czele podobno w drodze. Ze strony p[ana] Radeckiego mogę liczyć na dużą pomoc i ułatwienia. Jest to człowiek o dużej kulturze i bardzo dobrych chęciach, lecz będąc bez pomocników, nic nie może uczynić. Natomiast naczelnik policji p[an] Zaręba [?] i cała policja to wszyscy prawie szmuglerzy i łapownicy.

Co do pracy mojej tu zamierzam zorganizować na dużą skalę kolportaż pism i broszur i zakładać na razie w przyległych gminach, potem zaś w miarę rozwoju i w dalszych „Koła Młodzieży”, które jak sądzę będą się cieszyły wielka popularnością.

Zamierzam również w kontakt wejść z Polsko-Amerykańskim Komitetem Pomocy Dzieciom i stworzyć miejscowe komitety rozdzielcze przy szkółkach.

W samym zaś Brasławiu zamierzam założyć „Dom Ludowy” oraz zwołać na jeden z dni świątecznych wiec, aby zapoznać ludność z sytuacją obecną.

\section{\& Dokument 2}

Tabela opracowana przez JGK na podstawie dwóch dokumentów:

1. Pierwszy łotewski spis powszechny ludności w trzech powiatach Łatgalji według miejscowości i narodowości. Z dn. 15 VI 1920. [Wypis podpisany przez Antoniego Romera] [adnotacja: Widział Strauch 21 III 1921] [AAN TSK 105 k. 25, 26, 27, 28] ${ }^{62}$

Zaopatrzony uwaga AR,Władze łotewskie przy spisywaniu ludności usilnie starały się zmniejszyć liczbę Polaków na korzyść liczby Litwinów, a zwłaszcza Białorusinów co wielokrotnie stwierdziłem było, wobec czego spis niniejszy uważany być powinien za krzywdzący Polaków a faworyzujący natomiast Litwinów, a zwłaszcza Białorusinów”.

2. „Przebieg Polskiej Akcji Wyborczej do Sejmu Łotewskiego w Rydze” Wilno 2 XII 1922, J. Wiścicki AAN TSK 106 k. 54-72 rkps]

[Kompilacja $\mathrm{z}$ fragmentów tabeli przechowywanej w ANN z pominięciem kategorii: Łotysze, Wielkorusowie, Litwini, Żydzi, Niemcy, Estończycy, inni, niewiadomi, mężczyźni, kobiety. Ostatnia kolumna dodana na podstawie pełnej wersji dokumentu 2]

\begin{tabular}{|l|l|l|l|}
\hline POWIAT DYNEBURSKI & Białorusów & Polaków & $\begin{array}{l}\text { Głosów w 1922 roku } \\
\text { oddanych na Polaków }\end{array}$ \\
\hline Dyneburg [miasto] & 2164 & 8178 & 3339 \\
\hline Krasław [miasto] & 794 & 506 & 766 \\
\hline Kreutzburg [Kryżborg] [miasto] & 15 & 20 & \\
\hline Dagda [miasto] & 92 & 206 & 180 \\
\hline Głazmanka [miasto] & --- & --- & \\
\hline Liwenhof [miasto] & --- & 18 & \\
\hline Prele [miasto] & 12 & 164 & \\
\hline Wyszki [miasto] & 69 & 22 & \\
\hline
\end{tabular}

${ }^{62}$ Materiały te zostały wykorzystane i opublikowane przez E. Maliszewskiego w 1922 roku z pominięciem adnotacji i autoryzacji przez Antoniego Romera. 
STOSUNEK PAŃSTWA ŁOTEWSKIEGO DO MIEJSCOWYCH POLAKÓW...

\begin{tabular}{|c|c|c|c|}
\hline Dagda - gmina* & 599 & 705 & \\
\hline Gmina izabelińska* & 3163 & 889 & 541 \\
\hline Gmina Jaszmujzka* & 256 & 792 & 124 \\
\hline Kapińska* & 1950 & 1719 & 219 \\
\hline Kołupska* & 323 & 301 & \\
\hline Krasławska & 1178 & 1473 & 663 \\
\hline Kreutzburska [kryżborska] ${ }^{*}$ & 95 & 117 & \\
\hline Liksnieńska* & 19 & 605 & \\
\hline Liwenhowska & 28 & 57 & \\
\hline Malinowska* & 1510 & 245 & 130 \\
\hline Osuńska* & 1034 & 310 & \\
\hline Prelska* & 26 & 231 & 67 \\
\hline Ungermujska* & 274 & 23 & \\
\hline Użwałdzka* & 2083 & 230 & 119 \\
\hline Wyszkowska* & 234 & 768 & 176 \\
\hline Warkowska* & 552 & 317 & 97 \\
\hline Razem w miastach & 3146 & 9114 & \\
\hline Razem w gminach & 15324 & 8782 & \\
\hline ogółem & 18470 & 17898 & $\begin{array}{l}\text { *Przydrujsk } 363 \\
\text { *Pustyń } 356 \\
\text { *Straniewska } 44\end{array}$ \\
\hline $\begin{array}{l}\text { POWIAT LUCYŃSKI } \\
* \text { (gminy istniały w 1905) }\end{array}$ & Białorusów & Polaków & \\
\hline Lucyn [miasto] & 1555 & 290 & 198 \\
\hline Korsówka & 28 & 153 & \\
\hline Baltynowo [miasto] & 12 & 6 & \\
\hline Bołowsk [miasto] & 21 & 3 & 17 \\
\hline Poliszczyno [Poliszczyzna] [miasto] & 324 & 7 & \\
\hline Rozenówka [miasto] & 221 & 107 & 96 \\
\hline Rundany [miasto] & 25 & 1 & \\
\hline Stara Słoboda [miasto] & 222 & --- & \\
\hline Marjeuhauz (Wilaku) [miasto] & 18 & 27 & \\
\hline Gmina Bołowska* & 146 & 79 & \\
\hline Baltynowska* & 402 & 52 & \\
\hline Domopolska* & 90 & 98 & \\
\hline Ewersmujzka* & 147 & 121 & 7 \\
\hline Istrańska [Istrzańska] & 5096 & 82 & 34 \\
\hline Janowolska* & 2008 & 23 & \\
\hline Kokorewska & 66 & 17 & \\
\hline Korsowska* & 182 & 183 & 63 \\
\hline Lanckorona [lanckorońska] ${ }^{*}$ & 1440 & 242 & 19 \\
\hline Lipnieńska & 126 & 12 & \\
\hline
\end{tabular}




\begin{tabular}{|c|c|c|c|}
\hline Michałowska* & 2138 & 77 & \\
\hline Nerzańska* & 244 & 88 & 25 \\
\hline Pyłdzieńska* & 1407 & 429 & 145 \\
\hline Posińska* & 4750 & 496 & 320 \\
\hline Rundańska* & 1799 & 295 & 86 \\
\hline Zalmujzka* & --- & 5 & 1 \\
\hline Zwirdzińska* & 146 & 183 & 37 \\
\hline \multirow[t]{3}{*}{ Marjenhauzka (Wilaku)* } & 94 & 179 & 29 \\
\hline & 2426 & 594 & \\
\hline & 20881 & 2661 & \\
\hline ogółem & 23307 & 3255 & $\begin{array}{l}\text { *Tałkowo } 16 \\
\text { *Kaczanowo } 4\end{array}$ \\
\hline \multicolumn{4}{|l|}{ POWIAT RZEŻYCKI } \\
\hline Rzeżyca [miasto] & 126 & 1231 & 550 \\
\hline Andrepno & 23 & 17 & 104 \\
\hline Kownaty & 6 & 6 & 101 \\
\hline Małta & 1 & 25 & \\
\hline Rybiniszki & --- & 10 & \\
\hline Warklany & 6 & 39 & \\
\hline Wielony & 113 & 34 & \\
\hline Bykowska gm.* & 6 & 12 & \\
\hline Berżygalska & 160 & 130 & \\
\hline Ataszyńska & 54 & 6 & \\
\hline Andrepnieńska* & 228 & 663 & \\
\hline Makaszańska* & 1541 & 258 & 4 \\
\hline Uzułmuj(ń)ska* & 1 & 170 & 33 \\
\hline Rozenmujska* & 1599 & 621 & 118 \\
\hline Rozentowska* & 495 & 944 & 149 \\
\hline Sar(ks)tygalska* & 996 & 97 & 16 \\
\hline Sołujońska* & 21 & 469 & 60 \\
\hline Wajwodowska* & 1884 & 628 & 1 \\
\hline Bork(ch)owska* & 91 & 16 & \\
\hline Drycańska* & 35 & 35 & 15 \\
\hline Galańska* & 4 & 19 & \\
\hline Kownacka* & 1135 & 443 & \\
\hline Rudzacka & 1 & - & 6 \\
\hline Rużyńska* & 4098 & 24 & \\
\hline Sterniany* & 8 & 6 & \\
\hline Warklany* & 238 & 55 & 13 \\
\hline Wielońska* & 485 & 80 & 24 \\
\hline $\begin{array}{l}\text { Brak istniejących w } 1905 \text { roku } \\
\text { gmin: Kulniewskiej }\end{array}$ & & & $\begin{array}{l}\text { *Bykowo } 2 \\
\text { *Sterwiańska } 1\end{array}$ \\
\hline
\end{tabular}




\section{\& Dokument 3}

1920, grudzień/1921 styczeń. Łotwa i stosunki polsko-łotewskie w końcu 1920 roku i na początku 1921. Lietuvos Centrinis Valstybes Archyvas Fond 22 Apis. 1. Byla 6 lap. 36-40. Podp. Wacław [nieczyt.: Szarlurej?] starosta brasławski

Oparliśmy się na północnych rubieżach Rzeczypospolitej Polskiej o dziwnych przyjaciól, o tych przyjaciół, dla większości których dźwięk słów „Polska”, „Polak” jest dźwiękiem brzmiącym wrogo, dla których niepowodzenie nasze do niedawna było tem, z czego zupełnie otwarcie cieszono się. Bo też i przyjaźń zapoczątkowana na podstawach dziecinno-politycznego altruizmu, w nadziei na przyszłą bezgraniczną, bezinteresowną przyjaźń narodu łotewskiego za pomoc okazaną i krew przelaną we wspólnej walce o niepodległość Łotwy, o zjednoczenie takowej na krwawych w dziejach polach Inflant Polskich, nie mogła dać innych wyników, jak nienawiść do wszystkiego co polskie na ziemiach Łatgalii (Inflant Polskich). I dzisiaj stoimy przed początkiem końca dziejów Inflant Polskich.

\section{Stosunki}

Należy przypomnieć o dwóch nader charakterystycznych wypadkach. Pierwszy na terenie stolicy Inflant w Dyneburgu, inspektor szkolny wizytujący szkołę polska w Dyneburgu ujrzał na ścianie dwa portrety Sienkiewicza i Piłsudskiego, na widok których wpadł w tak szalony gniew, że zdarł portrety ze ściany i dyscyplinarnie ukarał przewodniczącą szkoły. Drugi, na terenie miasta Rzeżycy, gdzie przy analogicznych wypadkach została zdarta ze ściany i skonfiskowana mapa z granicami dawnej Polski.

\section{Pozycja ludności polskiej}

Ludność polska na Inflantach pozostaje nadal niemal bez opieki, obijając progi ministerstw, konsulatów i ambasad, wszędzie odprawiana z kwitkiem, bowiem ministerstwa nie potrzebują być „plus catolique que, que le Pape” zaś konsulaty i ambasady, składające się przeważnie z ludzi, którzy znają Łotwę i Inflanty, ponieważ mieli przyjemność poznać paru baronów kurlandzkich (podobno autentyczne z pierwszym ambasadorem polskim na Łotwie), lub z tych, którzy wychowani na ziemi galicyjskiej tyle mają pojęcia o Łotwie i Inflantach, co o Honolulu, mają jedyną odpowiedź na prośby: „nie możemy zaczepiać naszych jedynych sojuszników. Inaczej trudno sobie przedstawić, aby od początku istnienia ambasady polskiej na Łotwie ani pierwsza ani drugi poseł nie znaleźli parę dni czasu, aby zwiedzić Dyneburg i Rzeżycę, zapoznać się z tym krajem i ze społeczeństwem polskiem, pracującym na tak trudnem polu, aby ochronić polskość od zagłady".

\section{Początek końca}

I Łotwa grzmi. Nie przyznana jeszcze przez nikogo na szerokim świecie jako niezależne państwo wydaje przez swą konstytuantę prawa, które zastosowuje z całą bezczelnością nowo narodzonego do wszystkich obco poddanych. Ustawa o reformie rolnej 
opiewa ani mniej, ani więcej - właściciel posiadłości będzie miał prawo otrzymać kawał ziemi taki, jaki powinien być wystarczający dla „średniej gospodarki” bez koniecznego związania takowego z fundum. Oznacza to, że o ile gmina określi średnią gospodarkę na 5-10 dziesięcin, co stanowi 10-20 morgów, to właściciel posiadłości będzie mógł otrzymać takowe np. w końcu pola w zależności od widzimisię gminy. Rekompensata ma być określana przez inną ustawę prawną, ziemia zaś odbiera się obecnie, aby zaś państwo na niczem nie traciło najpierw zostały uzyskane podatki z pól, łąk i lasów i wody - do $15 \mathrm{rb}$ łotewskich z dziesięciny, czyli wg kursu na Łotwie $45 \mathrm{mk}$ polskich. Szereg majątków polskich już podlega parcelacji, a więc na 7 stycznia w gminie Rozentowo została ogłoszona parcelacja majątków: Prezma Władysława Sołtana, Małta pani Butkowskiej, Gorykołna Filipa Bohomolca. Kto chce kupić, ma prawo składać podaniu. Niemal jednocześnie I szwadron kurlandzki i 3 pułk łatgalski uznały za właściwe w barbarzyński sposób postarać się, aby zetrzeć z oblicza ziemi resztki biblioteki w Prezmie p[ana] Wł[adysława] Sołtana, składającej się do niedawna z 16000 tomów i częściowo ograbionej przez bolszewików, którzy jednakowoż znając wartość takowej, cenniejsze dzieła wywieźli. Określone wypadki tyczą się własności polskiej, o której ani rząd polski ani ambasada nie zakłócają słodkiego uśpienia. Trzechsetletnia kultura polska została w dniach wyzwolenia skazana na zagładę i ściera się z oblicza tej ziemi, synowie której ongi „Wolni, wolnie ku wolnej” Rzeczypospolitej zostali przyłączeni i wiernie trwali aż do dni wskrzeszenia, a dziś krwawemi sercami pytają, czy zacz mają Ojczyznę i czy polskość na Inflantach, co oparła się Niemcom, Rosjanom i bolszewikom zostanie zgładzona przez „dziwny sojusz”.

\section{Walka $\mathrm{z}$ katolicyzmem}

Równolegle z walką o zagładę polskości na Inflantach został podjęty sztandar walki przeciwko katolicyzmowi, bo wszak Inflanty są na wskroś katolickie. Co dwór, to Kościół. To Inflanty (Latgalya), a Kurlandya i Liflandia to protestantyzm. I nie pierwszy to okres tej walki w dziejach Łotwy. A więc religia w szkołach wywalczona paru głosami w konstytuancie została określona w programach szkolnych w następujący sposób: religia i etyka (religia dla wierzących), a dalej następuje biblia, Chrystus, Budda, Sokrates, Tołstoj itd.

Według zdania p[ana] Dyr.[ektora] Dep.[artamentu] Spraw Oświatowych p. Ausoja religia katolicka, to nawet nie religia. Dalej armia nie posiada ani jednego kapelana katolickiego. Żołnierz w niedzielę nie ma prawa pójść do kościoła na nabożeństwa. Kościół katolicki w cytadeli dynaburgskiej przeistoczony ongi na cerkiew rozsypuje się w gruzy, prośby zaś o zezwolenie na odprawienie nabożeństwa pozostają bez skutku. W majątku Lanckorona proboszcz zmuszony był uciec przed znęcaniem się żołnierzy łotewskich. Parafia pozostała bez kapłana. W $\mathrm{m}$. Osuniu proboszcz stacza ciągłe walki.

Biskup O’Rourke musiał ustąpić. Na jego miejsce został nominowany Łotysz ks. Spryngiewicz. I tu zaczęła się bajka. Rząd łotewski odmawia zapomogi. Biskup przyjeżdża do Uzwałdy konsekracja i ingres odbywają się w Agłeniu [Agłonie] (były 
klasztor koło Dyneburga). Na ingres zjechali się przedstawiciele władz i wojsk, na powitanie których ze strony biskupa zabrakło odpowiedzi. Dopiero w czasie obiadu biskup wzniósł toast, streszczający się do następującego zdania: „ponieważ kościół każe kochać ojca, matkę i ojczyznę, a więc niech żyje Łotwa”. Następuje obecnie głęboki zwrot duchowieństwa katolickiego ku Polsce. Ludzie nieprzejednani, widząc, iż katolicyzm będzie zwalczany przez rząd ze wszystkich sił zwracają swój wzrok ku Polsce, oczekując pomocy. I tutaj przedstawia się ogromne pole do działania. Lecz ambasada o niczem nie wie zajęta sprawami wyższej polityki.

\section{Stosunki w gminach}

Ogólne zdanie panujące wśród ludności to nie tylko nadzieja, że wojska polskie zajmą Inflanty, lecz przekonaniu, że stać się to musi. W niektórych gminach rzeżyckiego powiatu ludność oparła się poborowi jak np. w Andrepnie.

Nienawiść ku Łotwie Kurlandzkiej przejawia się dobitnie w znanym ogólnie przezwisku, określającym Łotyszów kurlandzkich „tschiuli”, co znaczy „czuchna”, w zamian Kurlandczycy nazywają Łatgalczyków „tschangala”. Różnica religii i języka daje swoje dobitne wyniki, zaś obsadzanie stanowisk w Łatgalii przeważnie przez „tschiuli” rozpala ogień nienawiści.

Nieprawidłowe rozporządzenia też nie wpływają na poprawę stosunków. Łatgalii zajmuje się szmuglem do Sowdepii. Aby zwalczyć takowy, zostało wydane rozporządzenie o zamknięciu granicy, lecz nie do Sowdepii, lecz między Kurlandią i Łatgalią. Cierpi na tym ludność cała. Rząd wywozi moc lnu i drzewa, przeważnie z majątków polskich, a w zamian nic nie daje, nawet ludność miejscowa nie zawsze ma możność otrzymania upaństwowionych lasów dostatecznej ilości surowca na wyroby drzewne.

\section{Sfery rządowe}

W sferach rządowych daje się zauważyć zwrot ku Polsce. Przyczyna - niejaka obawa przed Sowdepją. Niepewność jutra, koncentracja wojsk na granicach Łotwy i zrozumiałe, że bez oparcia o Polskę niezależność Łotwy nie może być utrzymana. Rosja Bałtyku nie daruje. Wcześniej czy później upomni się o wyjście na morze. I czas ten nie za górami. Najwięcej wysunięte ku północy starostwo brasławskie graniczące z Łotwa obejmowało sześć gmin kurlandzkich aż po Dźwinę, mających swoja nazwę „Zemgala”. Jest to część powiatu iłłuksztańskiego, położonego z prawej strony kolei żelaznej.

Obecnie toczą się pertraktacje między rządami Łotwy i Litwy (Kowieńskiej) w sprawie zamiany miasta Iłłukszty z częścią Kurlandii położonej z lewej strony kolei żelaznej na cząstek kolei prowadzącej ku Libawie przez Litwę przez stację Możejki. Sprawa ta wydaje się niemało ważna:

1/ ze względu na chęć Litwy posunięcia się na północ,

2/ ze względu na to, że prawa część w razie oddania lewej części Litwie straci dla Łotwy swą wielką wagę,

3/ ze względu na to, że granice Polski winne sięgać Dźwiny. 


\section{\& Dokument 4}

\section{1, luty, 16. Do Pana Kierownika Straży Kresowej powiatu brasławskiego p. Plewińskiego od instruktora J. Bitnera Okręg Wileński Towarzystwa Straży Kre- sowej powiat brasławski dn. 16 lutego 1921 L. p. 6. Raport. Poufne rkps. [odpis z odpisu] [AAN TSK 105 k. 17-21]}

Niniejszym komunikuję panu Kierownikowi o szczegółach mojej podróży do Dynaburgu o mojej działalności w nim. Po pierwsze przejście granicy łotewskiej związano obecnie z wielkimi trudnościami: dostatecznie powiedzieć, że przebierałam się przez 3 linii łotewskich i nie patrząc na to ryzykowałam głową, bo przede mną za kilka dni Łotyszy złapali polskiego szpiega i rozstrzelali jego. Przebrawszy do Dynaburga, od razu zwróciłem się do jednej pewnej osoby pani Jakubowiczówny, ale jak i spodziewałem się z początku spotkałem bardzo zimne przyjęcie, bo byłem przyjęty za prowokatora ([ja gawariła nijakich pisem izz za granicy nie ażidaju]) i tylko po przeczytaniu listu $\mathrm{p}$ [ana] Plewińskiego ${ }^{63} \mathrm{i}$ formalnego daprosu mnie o rozmaitych wybitniejszych osobach w Brasławiu otrzymałem niejakie takie zaufanie. Poznajmiłem się ze wszystkimi najwybitniejszymi Polakami w Dynaburgu i rozmówiłem się z każdym osobnie; na wieczór naznaczyłem posiedzenie dla omówienia sprawy. Co do charakterystyki tych osób, mogę powiedzieć następujące: po pierwsze panią [Ludmiłę] Jakubowiczównę, Polkę prezeskę Macierzy Szkolnej w Dyneburgu, kobieta dosyć energiczna, ale ciągłe [za] szpiegostwo prześladowana i donosy Łotyszy [sprawiają], że ta kobieta formalnie lęka się związywać w sprawy polityczne chociażby one i były korzystne dla Polski, na przykład w takiej sprawie jak moji [sic] przechowaniu [sic] (jako nielegalnego) spotkałem taką odpowiedź („Proszę Pana niech Pan prędzej wyjdzie, gdzieś urządzi się bo i Pana aresztują i mnie"). Następnie pan Próchnik. Polak, mężczyzna, który spółczuwa [sic], prace może pomóc w drobnych rzeczach ale broń Boże, żeby nigdzie nie wymienić ani jego, ani jego nazwiska, słowem spułczuwa [sic], ale do pomocy w prace nie nadaje się. Następnie pan Andruszkiewicz, Polak, patriota, ale pracy nie nadaje się, ale może dużo pomóc $\mathrm{w}$ drobnych rzeczach, ten pan ryzykując sztrafem i odpowiedzialnością, dał mnie u siebie przechowaniu i bardzo życzliwie odniósł się do sprawy, sam prawda nie ryzykując podjąć się pracować, ale poznajomił mnie z pewnym panem Pawlisem Łotyszem, który jest pewny człowiek; z tym panem ja miałem długa rozmowę: on zna stosunki w iłłuksztańskim powiecie i bierze się znaleźć odpowiednich ludzi z niektórych gmin wschodnich iłłuksztańskiego powiatu, które zgodziliby się pomóc w tej akcji, ten człowiek jest bardzo chciwy na pieniądze i za pieniądze może dużo zrobić; osobiście przy jego pomocy udało się mu przebrać z powrotem z Łatwi do Brasławia za 500 rb łotewskich. Następnie pan Stankiewicz, człowiek energiczny

${ }^{63}$ Jan Plewiński, akademik, słuchacz wydziału prawnego na Uniwersytecie Lubelskim. Organizował Koła Młodzieży w powiecie brasławskim i dziśnieńskim, kierownik brasławskiego Towarzystwa Straży Kresowej, po inspektora szkolnego w powiecie brasławskim, od 1 IX 1922 zaangażowany przez Związek Młodzieży Wiejskiej Ziemi Wileńskiej na instruktora objazdowego. LCVA Fond 172 ap 1 była 336 lap 48. Kwalifikacje pracowników ZMW ZW. 
może dużo pomóc w pracy, ale sam nie weźmie się, lęka się ryzykować głową. Na koniec pan Jan nazwisko nie chciał wymienić, lękając się nawet tego, ten człowiek dużo wie, ale barszo trudno jego pociągnąć za język, wszystko niektóre szczegóły od niego dowiedziałam się. Wot i wszystkie ludzie, z którymi ja potrafiłem zawiązać ścisłe stosunki. Przez ten dzień w kawiarni, narażając się na niebezpieczeństwo, zawiązałem rozmowę z Łotyszami policjantami i ostrożnie wypytywałem od nich o miejscowych stosunkach, o odnoszeniu ludności do Polski, Litwy i Łotwy. Zawiązałem rozmowę z ludźmi około konsulatu polskiego, od nich wypytywałem się o stosunkach, a także przez samego konsula Sytewicza i nawet $\mathrm{z}$ Łotyszami z łotewskiej stacji kontrolnej, ale więcej nie ryzykowałem, bo nie mając żadnych dokumentów, byłbym z pewnością aresztowany i rozstrzelany jako szpieg. Na wieczór u pana Andruszkiewicza zebrałam coś w rodzaju posiedzenia; na nim omówiłem sprawy, mając wiadomości z rozmaitych źródeł o powiecie iłłuksztańskim; sprawa do wykonania tylko w następujący sposób: na terenie powiatu brasławskiego jest dużo ludzi pochodzących ze wschodnich gmin powiatu iłłuksztańskiego; z tych ludzi trzeba zebrać delegację; następnie mając jakiś czy sfałszowany, czy legalny paszport łotewski i odpowiednią sumę pieniędzy przez uzyskanych ludzi uzyskać zgodę ludności wschodnich gmin powiatu iłłuksztańskiego. Następnie rozpowszechnić nielegalne jednorazowe wydanie (jakaś gazetka) z wpisaniem, że odbyła się delegacja z powiatu iłłuksztańskiego, następnie sama delegacja udaje się do Warszawy lub do Wilna do przedstawicieli koalicji z prośba o urządzenie na terenie tego powiatu plebiscytu, który rozumie się przy intensywnej robocie agitacyjnej wypadnie we wschodnich gminach powiatu dla Polski korzystnie; co do otrzymania delegatów wprost z powiatu iłłuksztańskiego to jest (w obecnych warunkach w Łatwi) niemożliwe do wykonania, bo żaden człowiek, samy energiczny nie zgodzi się wyjechać za Delegata, nie wiedząc na pewno, jaki będzie wynik i przez to [nie będzie] narażać siebie, żonę i dzieci na zemstę. Teraz w ogóle co do stosunków w iłłuksztańskim powiecie: ten powiat dzieli się na dwie części: wschodnią i zachodnią. O gminach leżących na zachód od miasta Iłłukszta można powiedzieć, że praca tam będzie bezowocna, bo większy procent ludności sta[no]wią tam Łotysze i nawet nastrój ludności jest dość przychylny do Łotwy; inaczej stoi sprawa w gminach wschodnich powiatu iłłuksztańskiego, tutaj ludność jest prawie cała katolicka, mieszana z Polaków i Litwinów, Łotyszów jest procent bardzo nieznaczny; ludność jest w większości dość przychylna do Polaków; częściowo do Litwy, ale ogromną szkodę urządza nam iskuśne rozszerzanie przez agitatorów pogłoski o nadużyciach polskich żołnierzy nad włościanami w powiecie brasławskim, tym czasem kiedy łotyszskie żołnierze zachowują się względem ludności (rozmaite nieprawne rekwizycje i rabunek) stosunkowo dobrze. Szkodzą nam także iskuśne rozduwane wiadomości o grużynie [drożyźnie?] i niskim stanie naszej waluty. Komisja aliancka, która przejeżdżała do powiatu, faktycznie nic nie zrobiła, bo ludność, lękając się terroru, wypowiedziała się tak („my wsjakoj Włast podczitlejem, a tat nam ljub kto z nas nje derjet”). Ale trzeba odnotować, że np. w gminie kałkuńskiej jest dość silna tendencja do Litwy. Ogólny nastrój ludności w Łatgalii jest „przekonanie”, że Polacy będą stać po Dwinie jako 
naturalnej granicy i jakoby termin ten obsadzenia linii Dwiny jest już wyznaczony. Co do polskiej inteligencji można powiedzieć, że ona jest w Łatwi „umierająca” nawet najmniejsza posada stróża i to Polak nie może zająć, nie wiedząc łotewskiego języka. Nauczycielstwo polskie, te pioniery polskości w Łatwi stanowczo mówią, że szkoły polskie będą zamknięte, jeżeli nie otrzymają zapomogi od rządu, bo nawet ta żebracza pensja 1000 rubli łotewskich miesięcznie nie otrzymują całą; urządzają wieczorki, przedstawienia, ale nawet i te źródła życia wskutek wrogiego usposobienia władz łotewskich do nauczycielstwa jako „palanizatorów” prędko znikną; można powiedzieć, że jeżeli w przeciągu dwóch miesięcy rząd polski nie przyjdzie z zapomogą, szkoły polskie staną $\mathrm{w}$ całej Łatwi; odczuwa się ogromne niezadowolenie $\mathrm{z}$ ambasadora polskiego w Rydze p[ana] [Witolda] Kamienieckiego, którego cała działalność zwodzi się do urządzania dla Łotyszów bankietów i polowania, nawet jak opowiadają kiedy do niego zwrócili się w sprawie iłłuksztańskiego powiatu to zapytał:

„A kto tam znajduje się Polacy czy Łotysze?” Można powiedzieć, że jeżeli takie stosunki potrwają jeszcze niejaki czas, to inteligencja polska w Łotwie skazana na zagładę. Wot i wszystko co ja wyniosłem ze swojej podróży. Przejście granicy z powrotem było związane z jeszcze większymi trudnościami niż wpierw, od Dźwińska szedłem 32 wiorsty piechotą, omijając żandarmów i przy pomocy p[ana] Pawlisa podkupiłem przez niego łotewskiego żołnierza i przejechałem granicę łotewską około Jakubowa. Słowem, sprawa jest możliwa do wykonania, ale takim sposobem, jak ją opisałem i potrzebuję łotewski paszport i pieniędzy. Pracownik Straży Kresowej Z. Bitner

19 / II [19]21

Za zgodność Pekszówna

Pieczęć okrągła napis w otoku *Towarzystwo Straży Kresowej*

\section{\& Dokument 5}

1921, marzec, przed 21. Do Kierownika Okręgu Wileńskiego. Raport kierownika powiatowego Towarzystwa Straży Kresowej. Stosunki pozafrontowe (Lotwa). Poufne. [Wpłynęło do kancelarii Głównej TSK 21 III 1921] [AAN TSK 105 k. 14-15]

Warunki, w jakich znajduje się ludność polska na terenie powiatu iłłuksztańskiego i na Inflantach dużo przedstawia do życzenia. Ucisk niesłychany, dochodzi do tego, że ludzie boją się mówić po polsku i używają języka rosyjskiego. Wywłaszczania prowadzone są w ten sposób, iż gmina każdorazowo ma decydować ile można danemu właścicielowi zostawić ziemi i jakie ma być odszkodowanie. Cała inteligencja posiadająca wyemigruje z Inflant i w ten sposób stracimy odwieczne nasze placówki terenowe, będące ośrodkami szerzenia polskości. Inteligencja pracująca również zamyśla o emigracji, wobec stanowiska władz łotewskich, które na najmniejsze nawet urzędy wymagają dokładnej znajomości języka państwowego. Polakom ziemi i nieruchomości kupować nie wolno. Uzyskanie odnośnego zezwolenia jest nader trudne i pociąga za sobą stratę czasu i zachodu . Szkoły polskie są stale redukowane, a na ich miejsce zakładane są 
rosyjskie, pomimo że istnieje dekret o swobodnym nauczaniu i że jeżeli w danej szkole jest więcej niż 30 dzieci, to szkoła przechodzi na koszt państwa.

Poza opłatą nauczycieli (1000 rb łotewskich) rząd nie udziela żadnej pomocy. Wszelkie pomoce naukowe muszą być zdobywane własnymi siłami. W Dyneburgu działa nieoficjalnie Polska Macierz Szkolna z panią Jakubowiczową i p[anem] Pruchnickim [powinno być Próchnikiem] na czele. Polska Macierz Szkolna zajmuje się finansowaniem polskich szkół, zdobywając fundusze z urządzanych zabaw, przedstawień itd. Wszystko to jednak nie wystarcza, a poseł polski w Rydze pan [Witold] Kamieniecki mino częstych obietnic, iż zajmie się gorąco szkolnictwem, do tej pory wyasygnował zaledwie $15000 \mathrm{rb}$ łotewskich. P[olska] M[acierz] S[zkolna] prosi o pomoc pieniężną w tej sprawie. Odnośny preliminarz już przedłożyłam [dokument w AAN TSK 105 k. 16]

Co do pracy naszej na terenie powiatu iłłuksztańskiego celem wyzyskania sporu litewsko-łotewskiego to zachodzą tu duże trudności z wynalezieniem odpowiednich, miejscowych ludzi, tak bowiem wielką jest obawa [przed] represjami, iż każdy boi się swego cienia. Można by zrobić dużo, lecz na to trzeba zdolnych ludzi, któryby tam stale zamieszkali i rozporządzili odpowiednim legitymacjami i dużymi środkami. Dość duże niezadowolenie jest z działalności posła w Rydze w Dyneburgu i konsula w Dyneburgu pana Szyrewica. Ten ostatni absolutnie nic nie robi celem ulżenia doli uciśnionym, nie widać żadnego poparcia dla usiłowań niektórych jednostek, dążących do organizowania życia polskiego, dla większego uodpornienia na zakusy nie tyle łotewskie, co rusyfikacyjne. Proszeni jesteśmy o dostarczenie książek szkolnych, zbiorku pieśni polskich, podręczników dla skautów (są dwie drużyny w Dyneburgu) oraz popularnych broszur. Cała trudność polega na przewiezieniu przez granicę, czego nikt, bojąc się rozstrzelania, podjąć się nie chce. Po długich staraniach udało się przemycić tam około 200 książek szkolnych oraz 100 naszych kalendarzy.

Reasumując powyższe, dochodzi się [do] wniosku, iż wśród sfer polskich na Łotwie jest dużo do zrobienia, trzeba tylko umieć ich zniechęcić i dopomóc, w tym celu należałoby wysłać dobrych instruktorów i dobrze zaopatrzonych, a praca ich wydałaby dobre rezultaty i byłaby bardzo pożądaną

Zob. też: AAN TSK 105 k. 1627 I 1921, Dynaburg. [Pismo] Do Zarzadu Straży Kresowej w Brasławiu. [podpisali] Prezes Zarządu Polskiej Macierzy Szkolnej w Dyneburgu L. Jakubowiczowa, sekretarz Próchnik

\section{\& Dokument 6}

1922, maj, 16. Stosunki polsko-łotewskie. Rządy łotewskie oraz nastroje polskie w Latgalii. Podp. JW. 16 V 1922 [AAN TSK 106 k. 9-21 mps] [Fragmenty]

[Stan ogólny w związku $z$ momentem politycznym] [--]

\section{Ogólna charakterystyka społeczeństwa polskiego na Łotwie}

Na ogół społeczeństwo polskie jak w Rydze, tak i w Dyneburgu da się zasadniczo podzielić na dwa obozy: jeden z nich skupia ludzi pracy, przeważnie ideowych, 
prawdziwych i szczerych Polaków, wojowników i dźwignie polskości, ludzi oddanych idei narodowej, aczkolwiek, rzeczywiście całkowicie lojalnych względem państwa łotewskiego; drugi obóz stanowią osoby, na których wyraźne piętno rosyjskie pozostawiło ślady, osoby z utraconym poniekąd obliczem narodowym, które dla celów osobistych w uszczerbek polskości oddają niemałe usługi rządowi łotewskiemu. Będąc oczywiście silnie przez czynniki rządowe popierane, mają tam wszędzie drzwi otwarte i zawdzięczając tolerancji władz łotewskich w stosunku do uprawianych przez większość z nich pasku oraz wszelkich komercyjnych kombinacji, nie wahają się szkodzić i tamować rozwój polskości. Na wszelkich uroczystościach i bankietach ośmielają się reprezentować i występować w imieniu całego społeczeństwa polskiego, pochlebiając władzom oraz wyrażając swoje zadowolenie z powodu ich rządów. Na szczęście grupa ta jest bardzo nieliczna. W Rydze koncentruje się koło Towarzystwa Auszra (Klub Towarzyski) w Dyneburgu reprezentowana przez pana Chaszkowskiego, kierownika wodociągów miejskich, pana Butkiewicza, pokątnego doradcy, pana Syrewicza byłego konsula polskiego w Dyneburgu oraz pana Kiełpsz, inspektora szkół polskich na Inflanty. Inny odłam reprezentuje w Rydze Towarzystwo „Oświata”, w Inflantach całe nauczycielstwo szkół polskich oraz szereg innych wybitniejszych na polu oświatowym i społecznym jednostek (pani Jakubowiczowa, Sosnowski i inni) ostatnia grupa pociąga za sobą całą ludność polską, która już zaczyna nieco w prawdziwych swych przyjaciołach się orientować.

Nieszczęściem było dla polskości Inflant, iż ten nieliczny a pozbawiony wszelkich pobudek narodowych odłam zagarnął całą władzę i reprezentację polskości i dopiero powoli zawdzięczając energicznym wysiłkom, daje się go od tego powoli odseparować (usunięcie Syrewicza). Antagonizm tych odłamów bezwzględnie szkodzi sprawie polskiej, gdyż tamci przez szereg intryg i podstępów, czując za plecami władzę łotewską, dotychczas jeszcze intrygują i starają się zabić wszelką inicjatywę zmierzającą do rozwoju życia narodowego. Obecny stan można scharakteryzować jako moment przełomowy zdepopularyzowania w oczach całego społeczeństwa polskiego garstki idących na pasku u rządu, która zaczyna tracić grunt pod nogami, niemało do tego przyczynili się konsul polski w Dyneburgu pan Świerzbiński, który dokładnie we wszystkie dziedziny życia polskości wnikał.

\section{Ogólny nastrój w Letgalii}

Ogólny nastrój ludności w Łatgalii da się streścić w paru słowach: „żyjemy pod znakiem tymczasowości”. Wszędzie słyszy się chłopskie rozumowanie, iż państwo, przez terytorium którego można „kamień przerzucić” samodzielnie długo trwać nie może, iż musi zajść jakaś zmiana. Stąd moc krąży rozmaitych sensacyjnych pogłosek. Najczęściej mówi się o przyjściu Polaków, nawet terminy są oznaczone. Oczywiście, że takie pogłoski tylko szkodzą sprawie polskiej na Inflantach, gdyż podrażniają władze, u których wzmaga się podejrzenie i nieprzyjaźń do ludności polskiej. Na ogół psychika mas nie otrząsnęła się spod wrażenia tylu przejść i zmian, jakie kraj inflancki spotkał, jako wynik niezadowolenia ze współczesnego status quo stara się 
pożądane, uważając za całkiem możliwe; stąd szereg sensacyjnych bezpodstawnych pogłosek o zmianie losu kraju. Raz po raz zjawiają się również pogłoski o przyjściu bolszewików, lecz te są znikome i rozgłosu nie mają. Głównym czynnikiem składającym się na niezadowolenie w stosunku do władz, to są wysokie i nadmiernie podatki, kompletny zastój życia przemysłowego i handlowego, nieudolne przeprowadzenie reformy rolnej, antagonizm w stosunku do Łotyszów kurlandzkich, zajmujących się omal że nie wszystkie stanowiska w Letgalii. Antagonizm ten ostatnimi czasy nieco się wzmaga, zawdzięczając agitacji księży, którzy operują argumentami odrębności religijnej, będąc silnie podrażnieni za oddzielenie kościoła od państwa.

\section{Nastrój ludności polskiej}

Ludność polska pozbawiona inteligencji, która już całkiem prawie wyemigrowała do Polski i stale stopniowo porzuca kraj rodzinny, znajdując się w stanie biernym i nie wykazując ruchliwości w kierunku zorganizowania się i walczenia o swe prawa. Będąc zastraszona i sterroryzowana ostatnimi prześladowaniami władz łotewskich, wykazuje swe poczucie narodowe jedynie silnym i nieprzepartym dążeniu kształceniu dzieci swych w szkołach polskich. Jedynie daje się zauważyć pewną ruchawkę w obronie swych praw i pewne tendencje do zorganizowania się u szlachty zagrodowej zwłaszcza u dzierżawców, w interesy których bezpośrednio godzi reforma rolna. Dyneburg posiadający obecnie według spisu łotewskiego 9000 ludności polskiej (ma 32000 ogółu) jest zupełnie niezorganizowany, gdyż inteligentne siły są liczone tylko na jednostki.

\section{Ruch białoruski}

O ile inteligencji polskiej sterroryzowanej i zastraszonej uniemożliwia się wszelką akcję narodową, o tyle białoruska inteligencja ma silne poparcie u władz łotewskich, które nawet współdziałają w rozwoju ruchu białoruskiego na niekorzyść ruchu narodowego polskiego. Akcja białoruska kierowana jest przez niejakiego Jezowitowa, byłego pułkownika armii carskiej, również pomagającego mu niejakiego Sacharowa, hojnie finansowo zasilana przez rząd Łastowskiego na Litwie zaczyna wydawać pewien plon. W Dyneburgu otwarte są kursa maturalne białoruskie, które obecnie liczą z 50 słuchaczy. Kursanci otrzymują pomoc materialną, zabezpieczającą przeciętny ich byt. Niedawno 18 osób po ukończeniu tych kursów zostało wysłanych do Pragi. Przy czem zapewniono im całkowite utrzymanie oraz 450 koron miesięcznie na każdego.

Wpływy akcji białoruskiej dosięgnęły i do katolickiego towarzystwa muzykalno-wokalnego „Harfa” opanowanego całkowicie przez żywioł polski. Kierownik tego Towarzystwa niejaki p. Mirowicz uznający siebie za Polaka, będąc materialnie zasilany przez kierownika ruchu białoruskiego, zaczął zdradzać tendencje białoruskie w kierowanym przez się Towarzystwie. Jednak zawdzięczając innym członkom towarzystwa, akcja ta była zniwelowana, a p. Mirowicz po pewnej konwersacji tete a tete z jedną z osób popularnych i cieszących się autorytetem wyrzekł się prowadzenia akcji białoruskiej, przyznając się do otrzymanych od nich pieniędzy i tłomacząc swój postępek nędzą materialną. 
Nauczycielka Polskiej Szkoły Kokińskiej gminy Izabelińskiej p. Banikiewiczówna, będąca, prawda, w pewnym podejrzeniu u społeczeństwa polskiego co do jej oblicza narodowego, podpadła pod wpływy białoruskie i ulegając namowie jej kierowników wystąpiła z wnioskiem do odnośnych władz łotewskich o przekształcenie szkoły polskiej na białoruską. Władze bardzo szybko na te sprawę zareagowały przychylną decyzją dla wnioskodawczyni. Skutek jednak był ten, iż po przekształceniu szkoły na białoruską zamiast 60 dzieci, jak poprzednio, uczęszczało 15\%.

Główny nacisk akcji białoruskiej jest skierowany przeciwko szkolnictwu polskiemu. Pan Jezowitow grozi nauczycielstwu polskiemu, iż zabierze wszystkich uczni polskich do szkół białoruskich. Prefektura miasta Dyneburga wyraźnie hołduje wszelkiej akcji białoruskiej w tym kierunku, nieraz dając dowody współdziałania Białorusinom w wykreślaniu z polskich szkół dzieci Polaków i przenosząc je do białoruskich, opierając się na tendencyjnym i wielce stronniczym spisie ludności w roku 1920, gdzie niemal że wszystkich Polaków zaliczono jako Białorusinów.

Tendencji kierowników ruchu białoruskiego zagarnąć pod swe wpływy staroobrzędowców licznie tam zamieszkujących pocierpiały całkowite fiasco. A rosyjskie społeczeństwo jest $\mathrm{w}$ wielkim $\mathrm{z}$ tym ruchem antagonizmie. Dla zobrazowania wszelkich wpływów w Łatgalii nie można nie pominąć i ruchu komunistycznego, który przy silnej obserwacji daje się zauważyć. Otóż o ile chodzi o całe państwo łotewskie, to wpływy te są tam bezsprzecznie duże, już chociażby i z tych względów, iż Łotysze odegrali i obecnie odgrywają niepoślednią rolę w sowieckiej Rosji. Granica łotewska ze strony Rosji jest obecnie strzeżona przez oddanych i świetnie uposażonych przez Rosję Sowiecką Łotyszów. Cała Łotwa roi się od agentów bolszewickich. Nie tak dawno został w Rzeżycy zaaresztowany niejaki Krampis sekretarz Zinowiewa, członek petersburskiego Ispołkomu. W Rydze też areszty komunistów są na porządku dziennym. Podpalenie gmachu Sejmu w Rydze również sprawa komunistów.

Za ostatnimi czasy (od czasu konferencji genueńskiej ruch łotewski wzmaga się: w Dyneburgu zaczął wychodzić ich tygodnik „Wolna myśl” pod płaszczykiem lewych socjał-demokratów. Proklamacje wzywające proletariat do organizacji przeciwko burżuazji oraz zapowiadające przyjście bolszewików często są na rynku znajdywane na podwórkach i na ulicy przez mieszkańców Dyneburga. Niemałe wpływy i sukcesy osiągnęli bolszewicy przy wyborach do ciał samorządowych gminnych. Miały za sobą ,element niezadowolonych z reformy rolnej, który daleko idącymi obiecankami w dziedzinie zreformowania reformy agrarnej dał się wyzyskać przez element o niskiej etyce i zdyskredytowanej w oczach społeczeństwa”.

\section{Reforma rolna}

Szerokie prerogatywy władzy w tej dziedzinie posiada zarząd gminny. Odebranie centrów właścicielom ziemskim, nadział ubiegających się o ziemie - wszystko to zależy od jego decyzji. [--] silnie daje się odczuć że kej ostrze [reformy rolnej] jest skierowane przeciwko stanowi posiadania polskiego oraz przeciwko ludności polskiej. Wywłaszczenie z centrów właścicieli pociąga za sobą również i stopniowe wysiedleni 
służby folwarcznej, jak również dzierżawców i połowników. Parcelacja folwarków należących do majątków, a od wieków dzierżawionych przez tak liczną szlachtę dobrze zagospodarowanych i zamożnych pozbawia całkowicie egzystencji, gdyż o ile otrzyma nadział, to musi pozbywać się inwentarza. O ile zaś zostanie pominiętym, to musi zwijać całe gospodarstwo [... ] Przy przeprowadzaniu reformy zaznaczył się wyraźnie nieprzyjazny stosunek władz do bezrolnej ludności polskiej. Dzierżawcowi Janowi Łukiańskiemu, gdy się rejestrował z zamiarem otrzymania ziemi agronom miejscowy, powiedział „ty Polak, tobie ziemia się nie należy”. Dzierżawcowi Fabianowi Tarwidowi władze gminne w ten sposób odpowiedziały „Ty szlachcic, tobie ziemi nie dany”

\section{Samorzą}

[Ministeria $w$ Rydze przed wydaniem decyzji zasięgaja opinii samorządów. Polacy członkowie samorządu sa celowo niepowiadamiani o ważnych zebraniach $i$ w ogóle traktowani sa bardzo nieprzychylnie. Wybory do Rady Miejskiej w Dyneburgu. Zebranie organizacyjne - [odbyło się] bez powiadomienia Polaków [--] w gminie kapińskiwej $w$ dniu wyborów wszyscy Polacy zostali wezwani do miejscowego agronoma co uniemożliwiło im udział w głosowaniu [---] W Rydze wśród 90 posłów Rady Miejskiej znalazło się 15 zadeklarowanych komunistów ${ }^{64}$

\section{Szkolnictwo polskie}

„Pomijając opłakany stan wewnętrzny szkół polskich i absolutny brak podręczników pomocy naukowych ciasnoty i niedogodności lokali szkolnych, wysokiej opłaty za szkołę (Gimnazjum w Dyneburgu i Rzeżycy), brak wykwalifikowanych i fachowych sił nauczycielskich, najrozpaczliwiej się przedstawia sprawa organizacji polskich władz szkolnych. Konsekwencje rusyfikatorskie i wielce szkodliwej działalności zmarłego p. Raczewskiego szefa wydziału szkolnictwa polskiego przy Ministerium Oświaty w Rydze dają się w rozwoju szkolnictwa polskiego na każdym kroku odczuwać. Zaangażowany przez niego, stosownie do jego intencji, personel techniczny wydziału szkolnictwa polskiego przyswoił prerogatywy władzy swojego szefa i kontynuuje nadal jego politykę. Niejaki pan Markowski, Sekretarz Wydziału, mając silne poparcie u panią Seil - vice ministra oświaty, a raczej całkowicie przez nią kierowany rozsyła bezsensowne i szkodliwe okólniki szkolnictwa polskiego, podpisując się za kierownika Wydziału. Co gorsza w czasie urlopu wymienionego wszelkie instrukcje i korespondencja do szkół polskich podpisywane są za kierownika wydziału przez niejaką kancelistkę tłumaczkę Łotewkę. Nauczycielstwo polskie jest bezsilne i wszelkie jego w tej mierze protesty nie dały żadnych wyników, gdyż personel wydziału jest pod całkowitą opieką

${ }^{64}$ Negatywną rolę w sprawie wyborów do Rady Miejskiej w Dyneburgu odegrał określany przez autora „raportu” mianem „pseudo-Polaka” niejaki Chaszkowski, który samorzutnie i bezprawnie zwołał zebranie w pierwszym terminie, by przeforsować własną kandydaturę. Sytuacja wykorzystywana była przez Łotyszy. W Centralnym Komitecie Wyborczym równoprawny udział mieli Żydzi, Rosjanie, Białorusini i Łotysze, Polacy zaś (według autora w liczbie 9000 w Dyneburgu reprezentowani przez pana Wierzbickiego) dysponowali jedynie głosem doradczym. 
szowinistki pani Seil. Już od kilku miesięcy stoi na porządku dziennym sprawa obioru kierownika wydziału szkół polskich. Sprawa jest na tyle paląca, iż nauczycielstwo polskie przywiązuje do niej kwestie bytu szkolnictwa polskiego na rok przyszły. Nauczycielstwo Letgalii pamiętne szkodliwej działalności pana Rączewskiego dąży do tego, aby zapewnić swój wpływ na wybór nowego kierownika, który by naprawdę interesów szkolnictwa polskiego bronił. Wysunięto kandydaturę pana Radena Edwarda, Inflantczyka, byłego kierownika szkół polskich na Syberii, człowieka energicznego i sprawie polskiej całkowicie oddanego. Kandydatura nie trafiła do przekonania Ministerstwu Oświaty i eo ipso wydziałowi polskiemu. Posypały się prowokacyjne insynuacje, szpiegowanie etc.

Doszło do tego, że wymieniony musiał zrezygnować i cofnął swa kandydaturę. $\mathrm{Na}$ ogół według prawa łotewskiego kierownika szkół mniejszości narodowych przedstawia frakcja mniejszości w Konstytuancie. Ponieważ Polacy nie mają tam swoich przedstawicieli, przeto w tym wypadku ma wybierać ogół wszystkich organizacji oświatowych polskich. Przeprowadzenie wyborów kierownika Ministerstwo Oświaty poleciło najbliżej stojącej jej organizacji Auszrze. Wobec bezczynności wydziału i braku choć najmniejszego zainteresowania się tym (pan Markowski pobiera podwójną pensję do czasu obioru nowego kierownika) sprawa ta się przewleka.

Nauczycielstwo Letgalii zainicjowało zwołanie zjazdu nauczycielskiego delegackiego, celem uregulowania i omówienia szeregu palących kwestii, na którym to [zjeździe] również projektowane [jest] poruszenie sprawy wyboru Kierownika Wydziału. Pan Minister Oświaty Dauge przyrzekł panu Jodce, iż na zwołanie zjazdu żadnych przeszkód stawiać nie będzie. Czynniki zaś wrogie rozwojowi szkolnictwa polskiego, na czele z panią Sejl, Wiceministrem Oświaty, zażądały wbrew zamiarom nauczycielstwa Inflant, które projektowało miejsce zjazdu Dyneburg, by odbył się w Rydze, następnie - aby zjazd był powszechny, a nie delegacki. [Pani Sejl] kategorycznie zastrzegła, aby na tym zjeździe nie była poruszona sprawa obioru Kierownika szkolnictwa polskiego. Ściśle określono porządek dzienny zjazdu, sprowadzając jego do spraw technicznych podrzędniejszej wagi, oraz wykreślono z porządku dziennego wolne wnioski. Organizacja zjazdu leży w rękach bezczynnego i szkodzącego sprawie szkolnictwa polskiego - wydziału polskiego. Przyszłość pokaże, jaki obrót przyjmie sprawa zjazdu jak również sprawa wyboru kierownika. Nauczycielstwo Inflant usposobione [jest] bardzo pesymistycznie, widząc iż wszelka jego akcja, wszelka inicjatywa zmierzająca do polepszenia bytu szkolnictwa jest na każdym kroku tamowana i paraliżowana.

Dziwną poniekąd rolę odgrywa w tym wszystkim p. Antoni Kiełpsz, inspektor szkół polskich na Letgalję. Po wysied[leniu] pana Kazimierza Próchnika, którego społeczeństwo polskie na to stanowisko wysuwało, został zamianowany przez pana Rączewskiego [wyżej] wymieniony [Kiełpsz]. Nauczycielstwo polskie absolutnie nie widzi w nim swego opiekuna i obrońcy swych interesów. Władze łotewskie absolutnie z nim się nie liczą. Są poważne dane, iż pan [Antoni] Kiełpsz zamierza awansować na kierownika wydziału, przeto stara się w niczem nie przeciwstawiać władzom, gdyż 
dotychczas jest uważany przez nie [za] jak najdalej lojalnie usposobionego. Będąc nauczycielem gimnazjum w Rzeżycy, nie wykazuje zainteresowania się szkołami polskimi w Letgalji. [---] Takich to oficjalnych obrońców swej sprawy ma nauczycielstwo polskie na Łotwie.

\section{[Sprawy gospodarczo-ekonomiczne][--]}

\section{Stosunek władz}

Wymienione powyżej fakta - stosunek do organizacji szkolnictwa i odmawianie prawa głosu decydującego przedstawicielowi polskiemu w Centralnym Komitecie Wyborczym do rady miejskiej w Dyneburgu, nie zezwolenie na przedstawienie polskie w Rzeżycy i szereg innych faktów dowodzą, iż obecny stosunek władz łotewskich bynajmniej na miejscu się nie polepszył. Społeczeństwo polskie nadal nieomal na każdym kroku odczuwa tę żywiołową poniekąd [niechęć] i wrogie stanowisko stojącej u władzy inteligencji łotewskiej.

\section{Perspektywy wyborcze w Latgalii}

Otóż najwięcej popularna przez radykalizm swych haseł w dziedzinie reformy rolnej podczas poprzedniej akcji wyborczej Konstytuanty Letgalska włościańska Partia (lista N 11), która pociągnęła za sobą nawet głosy bezrolnej ludności polskiej, obecnie zaczyna tracić grunt pod nogami. Słychać powszechne narzekanie na jej liderów za nieudolność i chaotyczność w dziedzinie przeprowadzania reformy agrarnej. Najwięcej zaś dyskredytujący ja wysuwany jest powszechny argument - zagarnięcie przez jej reprezentantów centrów majątków i w pierwszym rzędzie zaopatrzenie siebie w gospodarstwa o wyższej kulturze rolnej. Ważki ten argument ma być wysunięty przez inne rywalizujące $\mathrm{z}$ nią grupy. Mianowicie malkontentów ukrywających się pod firmą socjal-demokratów, bolszewików (lista N 4). Należy przypuszczać, iż dość popularny wśród proletariatu wiejskiego ta lista kierowana przez element wywrotowy wysuwający jak najradykalniejszy projekt przeprowadzenia reformy rolnej, projektując obdzielić absolutnie wszystkich bezrolnych i małorolnych, pozostawiając jako max 10 dziesięcin - pociągnie za sobą dość liczne grupy wyborców.

Druga grupa już poważniejsza, rywalka N 11, tak zwany blok chrześcijański (Organ Latgals worts w Rzeżycy), kierowana przeważnie przez księży, którzy nie mogąc zapomnieć rządowi oddzielenia kościoła od Państwa, ostygli w swym szowinistycznym zapale, daje się już odczuwać poważne aspiracje u nich w stosunku do państwowości polskiej. Grupa ta posiadając poważne wpływy na katolickie masy łotewskie, bezwzględnie podczas akcji wyborczej odegra niemało ważną rolę. Jaka postawę zajmie polskie społeczeństwo wobec tej grupy, jeszcze dotychczas nie zostało wyjaśnionym. Poważne racje przemawiają za blokiem $\mathrm{z}$ ta grupą.

\section{Sprawa pisma polskiego}

[- - ] 


\section{\& Dokument 7}

1922, wrzesień, 27. Raport ze stosunków na Lotwie. Inflanty 27 IX 1922. podp. J Wiścicki [AAN TSK 106 k. 24-31 mps] [Fragmenty] [Czynniki wpływające na bieg życia polskiego

Związek Polaków na Lotwie

Zarząd Związku Polaków na Lotwie

Rada Związku Polaków w Lotwie

Organizacja polskiej akcji wyborczej w Inflantach] [--]

Polska lista w okręgu letgalskim „[---] Księża łotewscy puścili pogłoskę jakoby polska lista ${ }^{65}$ jest katolicka, co podchwycił nr 4 - ks Wierzbicki i jego brat Jan, zmierzając do wykreślenia 1-3 [Antoniego Tałat-Kiełpsza, Stanisławy Dowgiałłównej, Jerzego Bryca] jako niewierzących, a nr 3 [Jerzego Bryca] - jako heretyka [--]”

\section{Perspektywy polskiej akcji wyborczej}

[--] „Na ogół polska akcja wyborcza posuwa się intensywnie, pomimo dużych braków jak

1) jałowy grunt - zbyt małe uświadomienie narodowe

2) brak środków

3) brak inteligentnych pomocniczych sił

${ }^{65}$ Polska lista kandydatów do Sejmu w Okręgu Letgalskim nr 14:

1. Antoni Tałat-Kiełpsz [prawnik Uniwersytetu Piotrogrodzkiego, inspektor szkół polskich]

2. Stanisława Dowgiałłówna [przyrodniczka uniwersytetu krakowskiego, prezeska Związku Polaków na Łotwie, dzierżawczyni m. Tawdowian]

3. Jerzy Bryc (rolnik) [wykształcenie wyższe, prawnik, energiczny, stanowczy, ścisły, rzeczowy; „rodzina p. Salewicza”, rolnik z powiatu dyneburskiego]

4. ks. Bronisław Wierzbicki, dziekan dyneburski [człowiek słabego charakteru, znajdujący się pod wpływem kleru łotewskiego]

5. Jarosław Wielpiszewski, prawnik [były działacz ziemski, rolnik pow. lucyńskiego, były sędzia ziemski, prezes (1922) Zarządu Gminnego]

6. Witold Lassan (Łossan), rolnik [prowadzi akcję pko nr 4 - ks. Wierzbickiemu; ściśle związany z liderami listy nr 19 Związku Drobnych Właścicieli i dzierżawców]

7. Ludmiła Jakubowiczowa [notariusz dyneburski]

8. Jan Wierzbicki, prawnik, [b. sędzia, obecnie nauczyciel szkoły polskiej]

9. Stanisław Wiścicki, rolnik

10. Michał Biedrzycki, dr med. [prezes Rady Miejskiej w Lucynie, b. szanowany i ceniony tak w mieście, jak i w powiecie, Prezes Koła Polskiego w Lucynie]

11. Adolf Giedrojć-Juraho, rolnik

12. Anna Koziczówna, rolniczka

13. Piotr Szyłan (Swyłan), buchalter $z$ Rygi, buchalter $\mathrm{z}$ konsulatu

14. Bolesław Wiszniewski, rolnik (Ryga)

15. Kazimierz Suprowicz, komornik sądowy (Libawa) [prezes towarzystwa polskiego w Lipawie] 
4) brak odpowiedniego sprężystego kierownictwa, gdyż Centralny Komitet Wyborczy zbyt ciążka machina, która w żaden sposób nie mogła dostosować się do wymagań akcji wyborczej. Na odbywających się raz w tygodniu posiedzeniach i odbywały się jedynie pogadanko i udzielały się informacje $\mathrm{z}$ miejsca.

Największymi rywalami dla listy polskiej są listy Nr 9 księży łotewskich oraz Nr 3 skrajnych socjalistów. Pierwsza prowadzona przez intensywną agitację z kościołów bije listę polską zarzutami, iż ona jest pańską i burżuazyjną oraz iż tam figurują heretycy, druga gra na instynktach klasowych i odciąga znaczna część polskiej służby folwarcznej oraz Polaków malkontentów z reformy rolnej.

Pokłada się dość duże nadzieje na wsie katolickie, ludność, których modli się po polsku, a rozmawia gwarą białoruską. Ludność ta gwałtownie dobija się szkół polskich, a nie chce narzucanych im szkół białoruskich, przez to niezupełnie powodzeniem cieszy się wśród nich lista białoruska Nr 21; łotewskie listy również nie cieszą się wśród niej powodzeniem, a ponieważ jest to ludność bardzo bogobojna, przeto nie ma tam wielkich wpływów skrajna lista nr 3; wszystko to składa się na to, że lista polska będzie miała tam powodzenie. Lista letgalska zawarła blok z polskimi listami w okręgu ryskim i okręgu kurlandzkim pod warunkiem, iż resztki na listy w powyższych okręgach będą przyłączone do listy letgalskiej. Ani Libawa (okręg kurlandzki), ani Ryga (okręg ryski) nie będą mogli uzyskać mandatów wobec braku polskiej ilości wyborców, przeto dość poważne resztki przypadną na listę letgalską. Przy zawieraniu bloku kandydaci z okręgu letgalskiego, którzy mieli figurować na liście O Ryskiego (Kiełpsz, Dowgiałłowa, Jakubowiczowa, ks. Wiezrzbicki) - zostali przez Ryską Okręgową Komisję Wyborczą skreśleni przy błahych zarzutach charakteru formalnego. [---] Okręgowa Komisja Kurlandzka przyjęła jedynie z listy letgalskiej kandydaturę księdza dziekana Wierzbickiego, natomiast kandydatury Kiełpsz, Dowgiałłówna i Iszyłana nie zostały dopuszczone, aczkolwiek z formalnej strony wszyscy odpowiadali tym samym wymaganiom co i ksiądz dziekan i oświadczenia, iż kandydaci się zgadzają były wypisane podług jednego szematu. Są to wszystko swoje kombinacje władz rządowych" nie dopuszczając pozostałych, którzy złożyli papiery wg dokładnie tego samego szematu.

\section{Sprawy szkolne}

$[--]$

\section{\& Dokument 8}

1922, grudzień, 2. Przebieg Polskiej Akcji Wyborczej do Sejmu Lotewskiego w Rydze

Wilno 2 XII 1922, J. Wiścicki [AAN TSK 106 k. 54-72 rkps] [Fragmenty]

\section{[Polski Centralny Komitet Wyborczy \\ Obwód ruszański}




\section{Obwód krasławski}

Obwód rzeżycki

Obwód lucyński] [--]

Nastroje i zachowania podczas wyborów ludności polskiej

O ile chodzi o nastroje oraz zachowanie się podczas akcji wyborczej ludności polskiej, to tutaj należałoby ludność tę podzielić na 3 grupy:

1) drobni i średni właściciele oraz dzierżawcy,

2) ludność wiejska,

3) służba folwarczna.

Otóż wśród średnich i drobnych właścicieli ziemskich oraz zamożniejszych dzierżawców napotykali przedstawiciele polskiej listy grunt podatni. Wszędzie wśród szlachty polskiej znajdowano zrozumienie i obiecywano listę polską popierać i rozpowszechniać. Jednak część dzierżawców, którzy nie zostali wyrugowani i zatrzymali posesje, obawiali się represji czynników rządowych niezupełnie przychylnie listę polską przyjmowali. Nietrudno to całkiem wytłumaczyć, gdyż zdani na łaskę i niełaskę rad gminnych bali się, aby nie wyrzucano ich jako Polaków, gdyż jako takich niedużo zostało przy dawnej dzierżawie.

Dzierżawcy wyrugowani już, bez przytułku szukali sprawiedliwości i zadośćuczynienia u partii lewicowych mianowicie tak popularnej listy N 3 (lewych socjaldemokratów bardzo zbliżonych swym programem do komunistów). Między innymi z tej partii nieliczna garstka tych agitatorów Polaków grasowała wśród szlachty niezamożnej polskiej i przeciwstawiała hasłom narodowym hasła klasowe. Wśród elementów mało uświadomionych i rozżalonych, rozgoryczonych i pokrzywdzonych miała ona posłuch.

Wioski polskie, czyli takie, których polskość polega na tym, iż ludność modli się z książek polskich i gwałtownie dobija się szkół polskich aczkolwiek rozmawia gwarą prostą, czyli „tutejszą" jak tam na miejscu nosi ona nazwę. Otóż te wioski były przychylne dla sprawy polskiej - przeważnie w okolicach, gdzie funkcjonowała szkoła polska, wpływów narodowych, której kwestionować nie można, na ogół argument - żądanie szkół polskich i obrona szkolnictwa polskiego wśród tej ludności był najskuteczniejszy i najwięcej trafiał do przekonania”. „W wioskach tego rodzaju (polskich) innych oddalonych od środowisk tego rodzaju, jak szkoła polska poza jednostkami całkowicie uświadomionymi, których może były tylko nieliczne garstki, decydowało przeważnie stanowisko księdza, czyli - na tamtejsze stosunki - lista n 9 - łotewsko-księdzowska, która pociągała elementy religijne i starsze, aczkolwiek młodzież tych wiosek oddawała przeważnie głosy na listę lewych socjaldemokratów (nr 3).

Najprzychylniejsze dla sprawy polskiej okazały się wioski takie w gminie krasławskiej i izabelińskiej, puszyńskiej, mniej przychylne w gminie kapińskiej.

Dość charakterystyczne przyjęcie miał przedstawiciel polskiej listy w gminach białoruskich powiatu lucyńskiego. Powiat lucyński liczy się z ostoją akcji białoruskiej. Otóż w gminach istriańskiej, janowalskiej, rundańskiej - przedstawiciel polskiej listy 
doznał wśród białoruskiej ${ }^{66}$ ludności nadzwyczajnie przychylnego przyjęcia. Jedyną petycją, i jedynym omal tematem to było kwestia utworzenia szkół polskich, obarczano nieraz prośbami napisania podania o szkoły polskie et cetera. Do narzuconych im szkół białoruskich odnoszą się bardzo nieprzyjaźnie i z dwojga złego wolą szkołę rosyjską niż białoruską.

Np. starają się o szkoły

1) W. Sawielinki, w. Źyżewo, Łamyszy (?), Rozenówka,

2) Radziszkino, Rakrzyno, Cibuli (?)

3) Romaszunki, Raknyno, Cibuli-Dubowniki i wiele innych wiosek.

Służba folwarczna wykazała pewną solidarność do popierania polskiej listy, mały odłam poszedł na lep haseł skrajnych. Większość miała oddać głosy na listę polską. Skutki wpływu kultury dworów polskich zwłaszcza obywateli ziemian, rozumnych i oświeconych nie kazały na siebie czekać. Wszędzie tam można znaleźć choć częściowo rozwinięte poczucie narodowe. Naturalny, niemały wpływ na przekonania służby folwarcznej wywiera[ją] interesy materialne. Większość ze służby, która otrzymała nadziały od rządu, już to przez wdzięczność, a prędzej przez bojaźń oddała głosy nie na listę polską, lecz na łotewską.

$\mathrm{Na}$ ogół na takie lub owe stanowisko ludności polskiej w Letgalii wpływał czynnik obawy, iż ten czyn, czyli fakt oddania głosu, pociągnie za sobą smutne konsekwencje; ludność ciemna, nieoświecona a sterroryzowana była niemało zdziwiona, że znalazł się taki, który przemawia do niej po polsku i że w ogóle polska lista istnieje, gdyż jak ona słyszała, że mowa polska zupełnie została zabroniona.

Nie zatarło się jeszcze i to złe wrażenie, jakie wywarło po kwaterunku żołnierza polskiego, bądź co bądź zdecydowało ono wśród pewnych rodzin w kierunku niegłosowania na swą rodzinną listę.

Jeden $\mathrm{z}$ bardzo ważnych czynników i kontrargumentów przeciwników polskiej listy było właśnie to, że nie posiadała ona programu społecznego, co prawda że ostatniego i posiadać nie mogła jako lista o charakterze ogólnonarodowym. Nieraz słyszano z ust Polaka wyborcy zapytanie, co polska lista może nam dać. Psychologia wyborcy pod wrażeniem agitacji i demagogii partyjnej w ten sposób się ukształtowała, iż liczyła się ona tylko z konkretnymi propozycjami odnoszącymi się do polepszenia jego bytu. Lista polska nie mogła dać rozwiązania kwestii rolnej, czy też innych socjalnych - co było w oczach mało uświadomionego wyborcy minusem. Plakaty i odezwy polskie będąc bardzo rozchwytywane spotykały się z tym zarzutem, iż nie wyłuszczają one programu polskiej listy.

\section{Akcja księdza Trasuna}

[Konkurencja Listy Nr 9 TRASUNA (?)((łotewsko-księdzowskiej) - zarzuty pod adresem listy polskiej: pańska, heretycka - (do heretyków zaliczono Kielpsza pochodzenia tatarskiego, Dowgiałtówne - jako socjalistkę, Bryca - studiującego okultyzm i filozofię akatolicką (świadomie - kandydującego Jerzego przyjęto za jego brata Stanisława)]

${ }^{66}$ Przekreślone „polskiej”, nadpisane „białoruskiej”. 


\section{Akcja lewych socjaldemokratów}

[Konkurencja Listy Nr 3 - argumentacje lewych socjaldemokratów - lista polska lista obszarników, lista zwolenników powrotu pańszczyzny, krzywdą nadzielonych ziemia. Wśród agitatorów listy Nr 3 byli Polacy, używano struny terroru - „kto nie głosuje zostaje rozliczony $w$ przyszłości", natężona agitacja $w$ wioskach biedniejszych i niełotewskich, zabrała duża liczbę głosów, na które liczyli Polacy i głosy Staroobrzędowców popierających program społeczny]

\section{Akcja Kempisza}

[Lista Nr 10 „Lista Narodowego Zjednoczenia” - rodowici Łatgalczycy tylko w Rzeżycy.]

\section{Akcja Pabierża}

[Partii zwycięskiej w poprzednich wyborach, przezwanej centowokami od zagarniania na skale masowa odbieranych od obywateli dworów; była to partia, która przyczyniła polskiemu społeczeństwu dużo przykrości w swej polakożerczej akcji; stała nagonka przeciwko szkolnictwu polskiemu była prowadzona dzięki inicjatywie i poparciu lidera tej partii Jerzego Pabierża.]

„Partia ta usilnie popierała ruch białoruski w Łatgalii. Przedstawiciele tej partii w Sejmie zajmują stanowisko wiceministra oświaty. Pani Waleria Sejl wyraźnie faworyzowała szkolnictwo białoruskie, a wrogo i nieprzyjaźnie odnosiła się do szkolnictwa polskiego".

\section{Akcja białoruska}

Białoruska lista także poniosła całkowite fiasko, otrzymawszy głosów 6 razy mniej niż lista polska. Białoruska lista otrzymała w Latgalii 38730 kuponów, polska zaś 238479.

Wynik wyborów zadał kłam łotewskiej oficjalnej statystyce z 1920 roku na mocy której w 3-ch powiatach Letgalji liczy się 27220 Polaków, natomiast Białorusinów 55132.

Miasto Lucyn, gdzie ruch białoruski jest najbardziej wspierany, dało na polską listę 196 głosów, a na białoruską - 108 - według tejże statystyki podaje się dla Lucyna Polaków zaledwie 290 i Białorusinów 1555.

\section{System wyborczy}

[Głosowało w Latgalii 195000 osób przy ogólnej liczbie ludności 600 000. Na wybranie 1 posła - przy istniejącej frekwencji - trzeba było w Latgalii 7000 głosów]. 